\title{
浸透流解析に基づく反応透過壁工法の性能評価 とその最適設計法の提案
}

\author{
石森洋行 ${ }^{1} \cdot$ 勝見 武 $^{2} \cdot$ 深川良一 $^{3}$ \\ 1 学生会員 工修 立命館大学大学院 理工学研究科（テ 525-8577 滋賀県草津市野路東 1-1-1） \\ 2 正会員 工博 京都大学大学院 助教授 地球環境学堂 ( T 606-8501 京都府京都市左京区吉田本町) \\ 3 正会員 工博 立命館大学 教授 理工学部（T 525-8577 滋賀県草津市野路東 1-1-1）
}

\begin{abstract}
反応透過壁工法の最適な形状条件・材料条件（設計パラメータ）を決定するために, 設計パラメータと 反応透過壁系の性能の関係および反応透過壁系の性能と污染サイト特性の関係を調べた. 前者の関係は, 各設計パラメータに対する平面 2 次元浸透流解析によるパラメトリックスタディの結果から評価した. 一

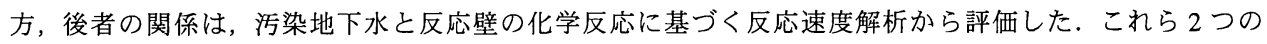
関係をもとに, 污染調査によって污染サイト特性がわかった場合の, 反応透過壁工法の最小施工費用を与 える最適な設計パラメータを最適化問題として整理し, その最適解を見出した. その結果, 反応透過壁工 法の最適な設計パラメータを污染濃度と污染範囲に基づいて決定する手法を提案した.
\end{abstract}

Key Words : contaminated groundwater, permeable reactive barrier, optimum design, seepage analysis, chemical reaction

\section{1. まえがき}

トリクロロエチレンや六価クロムをはじめとする 流動性の高い污染物質による地下水污染は, 地下水 流れに沿って帯水層中に広がり大規模な污染を引き 起こす場合が多い.わが国では, このような污染地 下水の浄化対策には, 初期コストや施設導入の容易 さから揚水処理が多く採用されてきた.この技術は, 特に污染源付近の高濃度領域を対象とした場合, 大 量の污染物質を短期間で回収できる利点をもつ.し かし, 帯水層に残存する污染物質を完全に除去する ことは難しいため, 長期の運転および維持管理が必 要となる.このため近年では, 維持管理コストの非 常に小さい反応透過壁工法が, 污染地下水の効果的 な原位置対策技術として注目を集めている.

反応透過壁工法は, 污染地下水が流れてくると予 想される場所に污染物質を浄化する機能をもつ壁 （反応壁）を設置し，污染地下水がその壁を通過す ることにより地下水を浄化する工法である. 反応壁 の材料は, 污染地下水と反応して無害化する反応剂 を, 透水性を確保するために砂および碟と混合し作 製する.これにより，地下水流れを損なわずに地下
水中に含まれる污染物質を処理することが可能とな る. また, 反応壁を帯水層中に設置すれば従来の対 策技術のような排水処理等は不要である. 反応透過 壁工法は, 自然な地下水流れにまかせて污染地下水 の浄化を行うので, 維持管理コストは小さくなる. 反面, 設備導入までに大規模な掘削工事を伴うこと から初期コストは高くなる傾向にある.

本文は, 反応透過壁工法の初期コストの低減を目 的として, 浸透流解析に基づいた反応透過壁工法の 最適設計を提案するものである. なお本文では, 帯 水層中の揮発性有機塩素化合物による污染を想定 し, 污染領域が特定されていることを前提にした最 適設計を提案している. また, 污染地下水の移流現 象のみを考慮して解析を行っており, 分散現象は無 視している，反応透過壁工法は，地下水流れがある 程度速い場合，すなわち分散よりも移流が卓越する 場合に適用性が高いと考えられるためである. 


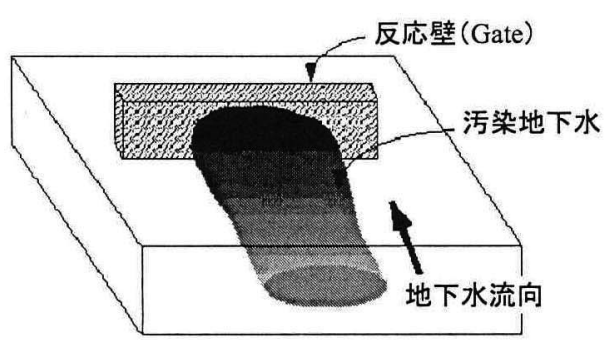

(a) Continuous PRB

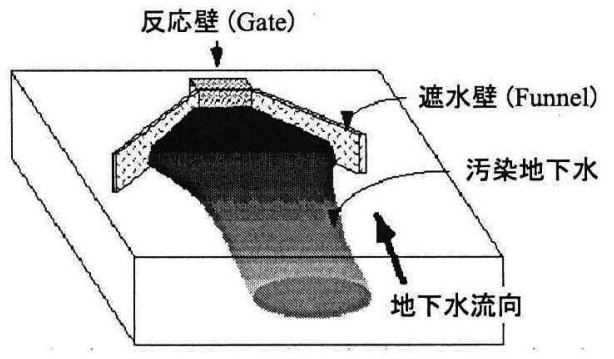

(b) Funnel-and-Gate System

図-1 反応透過壁工法の概念図

\section{2. 反応透過壁工法}

反応透過壁工法 ${ }^{1), 2)}$ は, Continuous PRB工法 (以下 cPRB) と Funnel-and-Gate System 工法（以下FGS）の 2 つに大別される。図-1(a)に示す cPRB は，地盤に透 水性の良い反応壁のみを設置し地下水流れを乱すこ となく污染地下水を浄化させるシステムである.こ れに対して，図-1(b) に示す FGS は，地下水流れを 遮水壁（以下 Funnel）で1ヶ所に集中させ,そこに設 置した反応壁（以下 Gate）を通過する污染地下水を 浄化させるシステムであり, cPRBに比べて低施工費 用で実施できる特長をもつ.

Gateに使用される反応剂には，活性炭などの物理 的な吸着性材料をはじめ, 微生物なぞの生物学的な 材料や，還移金属あるいはその化合物などの化学反 応を利用した材料があり，対象とする污染物質の性 質により多岐にわたる材料の適用が考えられる。そ のため, 反応剂を変えることで様々な物質による活 染に対応できる特長をもつ ${ }^{3)}$. 表-1に，Gateに使用 される代表的な反応剂を示す.

反応透過壁の浄化メカニズムは, 反応剂を含有し た Gate を污染地下水が通過することによって浄化さ れる. 通過中は Gate 内の反応剂と接触し, 化学反応 が生じる，一般に，反応剂には零価鉄粉 $\left(\mathrm{Fe}^{0}\right)$ が用 いられることが多く，それはTCEや Cr (VI)による活 染に詨して特に有効であるといわれている．前者は 鉄粉の腐食により TCE の脱塩素反応が生じ, 一方, 後者は鉄粉の腐食により $\mathrm{Cr}(\mathrm{VI})$ の還元反応が生じて

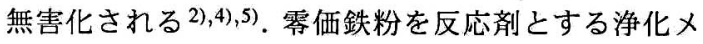
カ二ズムは, 主に脱塩素反応と酸化還元反応による ものであるが, Gate 内部での生分解反応により $\mathrm{NO}_{3}^{-}$ や $\mathrm{SO}_{4}^{2-}$ を除去した例 6),7) もある.

反応透過壁工法の設計手法はこれまで数多くの研 究者により研究されているが, その多くは cPRBに 関するものである. cPRB は地下水流況を乱す Funnel を設置しないため, 污染地下水は周辺地盤の動水 勾配, 流速を維持したまま, Gate を通過することが
表 -1 污染物質と反応剂

\begin{tabular}{|c|c|}
\hline 污染物質 & 反応剤 \\
\hline \multicolumn{2}{|l|}{ 【有機塩素系污染物質】 } \\
\hline PCE, TCE, DCE & $\mathrm{Fe}^{0}$ \\
\hline PCBs & $\mathrm{Pd} / \mathrm{Fe}$ (Bimetallic metal) \\
\hline \multicolumn{2}{|l|}{ 【重金属系污染物質】 } \\
\hline $\mathrm{Cr}(\mathrm{VI})$ & $\mathrm{Fe}^{0}$, Zeolite, SM slag \\
\hline $\mathrm{Cd}, \mathrm{Zn}, \mathrm{Cu}, \mathrm{Pb}, \mathrm{CN}, \mathrm{Hg}$ & Zeolite, SM slag \\
\hline \multicolumn{2}{|l|}{ 【窒素系污染物質】 } \\
\hline Nitrogen ammonia & Zeolite \\
\hline Phosporous & SM slag, Wastelime \\
\hline \multicolumn{2}{|l|}{ 【硫酸系污染物質】 } \\
\hline $\mathrm{SO}_{4}^{2-}$ & $\mathrm{Al}(\mathrm{OH})_{3}, \quad \mathrm{SM}$ slag, Wastelime \\
\hline
\end{tabular}

できる.したがって, 污染領域の鈶直断面積と同等の 断面積をもつ Gate を設置する必要がある。また，そ の Gate の厚さと充填すべき反応剂の量は, 污染地下 水と反応剂の反応速度より決定される. 反応速度は, 污染地下水と反応剂の反応を 1 次反応と仮定した反 応速度解析から評価される. 反応速度から污染地下 水が無害化されるまでの反応時間を評価し，その反 応時間以上の間, Gate内に污染地下水を滞留させる ように Gate の厚さと反応剂の量が決定される ${ }^{2)}$. 一 方, FGS は, Funnel の設置により, Gate 内の地下水 流速は周辺地盤のそれに比べて高くなり, また污染 地下水の捕捉範囲も複雑化する.このような流況変 動を定量的に評価することは困難であるため, 明確 なFGSの設計手法が確立されていないのが現状であ る. FGS の設計手法ないし，性能評価に関する研究

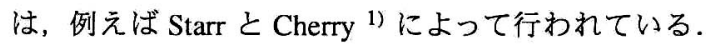
Starr とCherry は平面 2 次元飽和定常浸透流解析によ り, Gateを通過する地下水流量 (污染地下水処理量) に対する Gateの幅, Gateの透水係数, Funnelの幅の 影響を評価しており, また Funnel の角度の有効性を 地下水流向の点から評価している. その結果, Gate の透水係数を周辺地盤の 10 倍以上にしても処理効 果が向上しないと示されたが, 具体的な Gateの幅と Funnel の幅の值を決定するまで至っていない。 


\section{3. 污染地下水と反応剂の反応速度}

\section{（1）揮発性有機塩素化合物之零価鉄粉の反応}

揮発性有機塩素化合物と零価鉄粉の酸化還元反応 では，図-2に示すように零価鉄粉が水と反応して鉄 イオンに酸化される ${ }^{8)}$. 揮発性有機塩素化合物は, こ の酸化反応で放出された自由電子を受け取ることに より，脱塩（還元）されて無害化される.この脱塩素 過程は，次の反応式により表わされる9),10,11).

$$
\begin{array}{ll}
\mathrm{Fe}^{0} \longrightarrow \mathrm{Fe}^{2+}+2 \mathrm{e}^{-} & \begin{array}{c}
\text { 陽極反応 } \\
\mathrm{RCl}+2 \mathrm{e}^{-}+\mathrm{H}^{+} \longrightarrow \mathrm{RH}+\mathrm{Cl}^{-}
\end{array} \text {陰極反応 } \\
\mathrm{Fe}^{0}+\mathrm{RCl}+\mathrm{H}^{+} \longrightarrow \mathrm{Fe}^{2+}+\mathrm{RH}+\mathrm{Cl}^{-} &
\end{array}
$$

揮発性有機塩素化合物の代表的な污染物質である トリクロロエチレン（以下 TCE）やテトラクロロエ チレン（以下 PCE）は，1 分子中に 3 ないし 4 個の塩 素原子を有する，そのため, TCE や PCE と零価鉄粉 の反応は, 式 (1) が逐次的に起って, 最終的に塩素 原子の無いエチレンとなる.この遂次反応の詳細は 零価鉄粉や反応系の状態に依存するため明確に示す ことはできないが，大局的に図-3のように進むと考 えられている4).

\section{（2）反応速度解析}

反応透過壁工法の設計を行う際には，反応壁に流 れ込んだ污染地下水を清浄にするだけの浄化性能を もつように設計する必要がある。言い換えれば，污

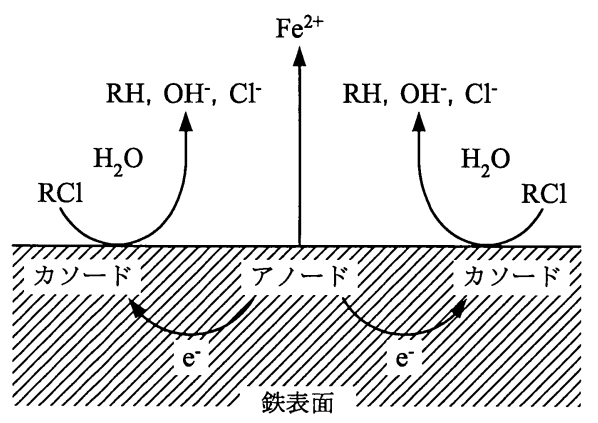

図-2＼cjkstart鉄表面における脱塩素反応の概念図
染地下水が反応壁を通過する時間（すなわち滞留時 間 : Retention Time）内に図-3 の脱塩素過程を進め, 人体に無害な物質, エチレンにまで変化させなけれ ばならない。このとき, 污染地下水が零価鉄粉と接 触し始めてから無害化されるまでの反応時間（以下 Residence Time）が重要になる.

Residence Time は, 次の連立常微分方程式を解くこ とにより計算される ${ }^{12), 13) .}$

$$
\begin{aligned}
& \frac{d[A]}{d t}=-\left(k_{S A}\right)_{A} a_{s} \rho_{m}[A] \\
& \frac{d[B]}{d t}=a_{s} \rho_{m}\left(\left(k_{S A}\right)_{A}[A]-\left(k_{S A}\right)_{B}[B]\right) \\
& \frac{d[C]}{d t}=a_{s} \rho_{m}\left(\left(k_{S A}\right)_{B}[B]-\left(k_{S A}\right)_{C}[C]\right) \\
& \frac{d[D]}{d t}=a_{s} \rho_{m}\left(\left(k_{S A}\right)_{C}[C]-\left(k_{S A}\right)_{D}[D]\right)
\end{aligned}
$$

ここに, $A$ :PCE, $B: \mathrm{TCE}, C:$ cis-1,2-DCE, $D: \mathrm{VC}$ を表わ ᄂ, $[A] \sim[D]$ : 各污染物質の濃度, $\left(k_{S A}\right)_{A} \sim\left(k_{S A}\right)_{D}$ : 比反 応速度定数 $[L / T], a_{s}$ : 反応剂比表面積 $\left[L^{2} / M\right], \rho_{m}$ : 反 応剂質量濃度 $\left[M / L^{3}\right]$ （単位体積の污染地下水に投与 する反応剂の総質量）を表わす．比反応速度定数 $k_{S A}$ は反応剤の単位表面積で標準化された反応速度定数 (減衰定数) $k[1 / T]$ を表わし 33,14$), 15), k=k_{S A} a_{s} \rho_{m}$ の関 係がある. 反応剤質量濃度 $\rho_{m}$ と反応剂充填率 $\phi[-]$ （反応壁の全固層（反応剂＋土粒子）体積に対する反 応剂体積の割合）の間には次式の関係が成り立つ。

$$
\rho_{m}=\phi\left(1-n_{\text {gate }}\right) \rho_{r} / n_{\text {gate }}
$$

ここに, $n_{\text {gate }}$ : 反応壁の（有効）間隙率, $\rho_{r}$ : 反応剂の 密度を表わす. 反応剂の量を表わすパラメータ $\rho_{m}$ と $\phi$ には互いに従属し合う関係にある. そのため以後,

\begin{tabular}{|c|c|c|c|c|c|}
\hline 生式 & ${ }_{\mathrm{Cl}}^{\mathrm{Cl}}{ }_{\mathrm{C}}=\mathrm{C}_{\backslash}^{\prime}{ }_{\mathrm{Cl}} \mathrm{Cl}$ & ${ }_{\mathrm{Cl}}^{\mathrm{H}}{ }_{\mathrm{C}}^{\mathrm{C}}=\mathrm{C}_{\backslash \mathrm{Cl}}^{\prime}$ & ${ }_{\mathrm{Cl}}^{\mathrm{H} \backslash}{ }^{\mathrm{C}}=\mathrm{C}_{\backslash}{ }_{{ }_{\mathrm{Cl}}}^{\prime \mathrm{H}}$ & ${ }_{\mathrm{H}^{\prime}}^{\mathrm{H}}{ }_{\mathrm{C}}=\mathrm{C}_{\backslash \mathrm{C}}^{\prime}$ & ${ }_{\mathrm{H}^{\mathrm{H}} \mathrm{C}^{\prime}} \mathrm{C}^{\prime} \mathrm{C}^{\prime}$ \\
\hline 物質名 & PCE & $\mathrm{TCE}$ & cis-1,2-DCE & $\mathrm{VC}$ & Ethene \\
\hline 地下水環境基淮値 & $0.01 \mathrm{mg} / \mathrm{L}$ & $0.03 \mathrm{mg} / \mathrm{L}$ & $0.04 \mathrm{mg} / \mathrm{L}$ & $(0.04 \mathrm{mg} / \mathrm{L})$ & None \\
\hline
\end{tabular}
反応剂の量を表わすパラメータは反応剂充填率 $\phi に$ 統一するものとする.

式 (2) の連立常微分方程式を解けば, 図-4 に示す ような曲線が得られる.この図から，污染物質 $\mathrm{A} \sim \mathrm{D}$ を所定の浄化目標濃度（ここでは，図-3に示す地下 水環境基準值を採用する）にまで減衰させるために 必要な Residence Time を次式により算出する.

注）VCの環境基準值は定められていないが，本文では $0.04 \mathrm{mg} / \mathrm{L}$ と仮定する.

図-3 PCE と零価鉄粉の代表的な反応経路 


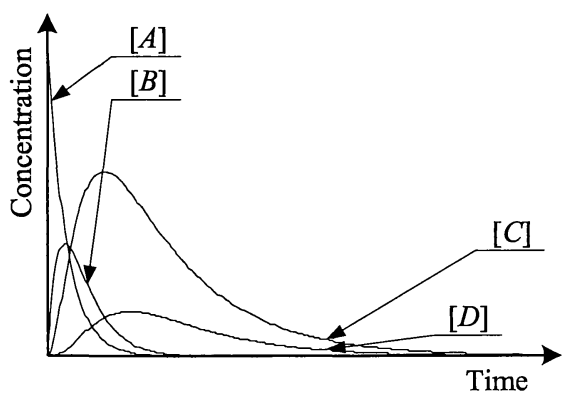

図-4 逐次反応における污染濃度と反応時間の関係

$$
\text { Residence Time }=\underset{P=A \sim D}{\operatorname{Max}}\left(\left.t\right|_{[P]=[P]_{\text {allow }}}\right)
$$

ここに, $P$ : 污染物質 $\mathrm{A} \sim \mathrm{D}$ を表わす指標， $[P]_{\text {allow }}:$ 励 染物質 $\mathrm{P}$ の浄化目標濃度（環境基準值）を表わす. 式 (2)より Residence Time を計算した例を表-2 に示す. 反応剂（鉄粉）の比反応速度定数は文献 12 ),13) を参考 にし, 污染濃度はTCEの飽和溶解度を参考にした。

計算結果である表 -2 をると, いかなる污染濃度 条件においても Residence Time は 1 日にも満たない 值となった．つまり，污染物質と反応剂を 1 日間も 接触させ続ければ，污染物質を十分に浄化すること ができる.したがって, 反応壁に流れ込んだ洉染地 下水を清浄にするだけの浄化性能をもつように設計 するためには, 反応壁内での泒染地下水の滞留時間 （Retention Time）を 1 日間程度確保すればよい. 地 盤中を流れる地下水流速を考えれば, 所要の浄化性 能をもつように反応壁を設計するのは容易であると 考えられる．なお本計算では，反応壁に流れ込んだ 污染地下水は必ず反応剂と接触するという仮定のも と計算している．反応刻充填率 $\phi$ が極端に小さい場 合，污染地下水が反応剂に接触しないまま反応壁を 通過してしまう可能性が高くなる。このときの Residence Time を式 (2)より評価すると, その值は実際よ りも小さくなり，反応壁が危険側に設計される，反 応剤充填率が小さい場合の Residence Time を評価す
る際には, 污染地下水と反応剂の接触確率を考慮し た上で, 反応速度解析を行う必要がある. しかしな がら, 反応壁の施工時において小さな反応剂充填率 （例えば， $\phi=5 \%$ ）の条件で反応剂之土を均一に混合 するのは難しいため, ある程度の反応剂充填率が必 要と考えられる，そのため，実務上での反応剂充填 率の範囲内では, 反応剂との接触確率を考慮せずと も, Residence Time が小さく評価されることはない.

\section{4. 反応透過壁工法の性能評価}

\section{(1) 概要}

反応透過壁工法の設計を行う際には, 前述した所 要の浄化性能をもつことに加えて, 污染地下水を捕 捉するための集水性能ももつように設計しなければ ならない. 浄化性能は污染地下水の Gate 内での滞留 時間（以下 Retention Time）で評価し，また集水性能 は污染地下水の捕捉幅（以下 Capture Width）で評価 することができる.これらは反応透過壁工法の設計 パラメータである幾何条件や物性条件に依存するた め, その依存性を平面 2 次元飽和定常浸透流解析か ら評価した。

\section{（2）基礎方程式}

地盤中の微小要素への質量収支を考え, 質量保存 則を導くと次式が成立する。

$$
\frac{\partial \rho \theta}{\partial t}+\frac{\partial \rho u_{i}}{\partial x_{i}}=0
$$

ここに, $\rho:$ 水の密度, $\theta:$ 体積含水率, $u$ : 地下水流 速を表わす. 地下水流速 $u$ は，ダルシーの法則を準用 して次式で与えられる。

$$
u_{i}=-K_{i j} \frac{\partial H}{\partial x_{j}}
$$

\begin{tabular}{|c|c|c|c|c|c|c|c|c|c|c|c|c|}
\hline \multicolumn{4}{|c|}{ 初期污染濃度（mg/L) } & \multicolumn{4}{|c|}{ 比反応速度定数 (m/day) } & \multirow{2}{*}{$\begin{array}{c}\text { 密度 }\left(\mathrm{g} / \mathrm{m}^{3}\right) \\
\rho_{r} \\
\end{array}$} & \multirow{2}{*}{$\begin{array}{c}\text { 比面積 }\left(\mathrm{m}^{2} / \mathrm{g}\right) \\
a_{s}\end{array}$} & \multirow{2}{*}{$\begin{array}{c}\text { 充填率 (\%) } \\
\phi \\
\end{array}$} & \multirow{2}{*}{$\begin{array}{c}\text { 間隙率 } \\
n_{\text {gate }} \\
\end{array}$} & \multirow{2}{*}{$\begin{array}{c}\text { Residence Time } \\
\text { (day) }\end{array}$} \\
\hline$[A]_{0}$ & {$[B]_{0}$} & {$[C]_{0}$} & {$[D]_{0}$} & $\left(k_{S A}\right)_{A}$ & $\left(k_{S A}\right)_{B}$ & $\left(k_{S A}\right)_{C}$ & $\left(k_{S A}\right)_{D}$ & & & & & \\
\hline 10 & 0 & 0 & 0 & & & & & & & 20 & & 0.044 \\
\hline 100 & 0 & 0 & 0 & & & & & & & 20 & & 0.058 \\
\hline 1000 & 0 & 0 & 0 & 5.04 & 9.36 & 9.84 & 1.20 & & & 20 & & 0.073 \\
\hline 1000 & 0 & 0 & 0 & $x$ & $\times$ & $\times$ & $\times$ & $6.8 \times 10^{6}$ & 0.10 & 5 & 0.45 & 0.290 \\
\hline 1000 & 0 & 0 & 0 & $10^{-2}$ & $10^{-3}$ & $10^{-4}$ & $10^{-3}$ & & & 10 & & 0.145 \\
\hline 1000 & 1000 & 0 & 0 & & & & & & & 20 & & 0.077 \\
\hline 1000 & 1000 & 1000 & 0 & & & & & & & 20 & & 0.079 \\
\hline
\end{tabular}

表-2 揮発性有機塩素化合物を環境基準值まで減衰させるのに必要な Residence Time の計算例

注) $A: \mathrm{PCE}, B: \mathrm{TCE}, C:$ cis-1,2-DCE, $D: \mathrm{VC}$ を表わす. 


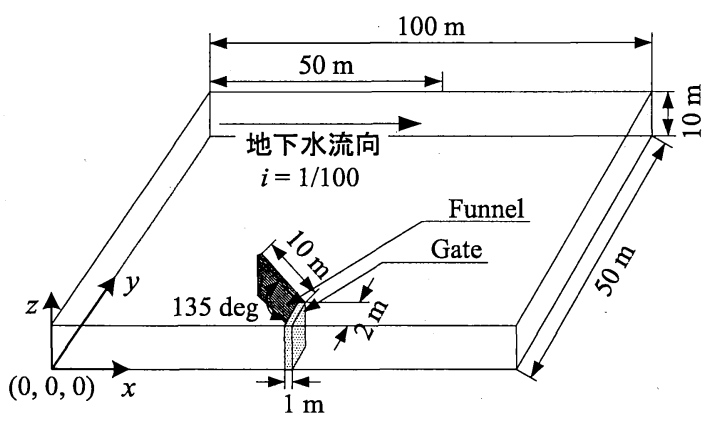

図-5 解析空間

表-3 解析条件

\begin{tabular}{c|c|ccc}
\hline & 単位 & 2D & Semi-3D & 3D \\
\hline 透水係数 & & & & \\
周辺地盤 & $\mathrm{cm} / \mathrm{s}$ & $5.0 \times 10^{-3}$ & $5.0 \times 10^{-3}$ & $5.0 \times 10^{-3}$ \\
Gate & $\mathrm{cm} / \mathrm{s}$ & $5.0 \times 10^{-2}$ & $5.0 \times 10^{-2}$ & $5.0 \times 10^{-2}$ \\
Funnel & $\mathrm{cm} / \mathrm{s}$ & $5.0 \times 10^{-6}$ & $5.0 \times 10^{-6}$ & $5.0 \times 10^{-6}$ \\
\hline 有效間隙率 & & \multicolumn{3}{|c}{} \\
周辺地瞥 & - & & 0.30 & \\
Gate & - & & 0.30 & \\
Funnel & - & & 0.15 & \\
\hline VG パラメータ: $\alpha$ & & & & \\
周辺地盤 & $1 / \mathrm{cm}$ & & & 0.138 \\
Gate & $1 / \mathrm{cm}$ & & & 0.138 \\
Funnel & $1 / \mathrm{cm}$ & & & 0.005 \\
VG パラメータ: & & & & 1.592 \\
周辺地盤 & - & & & 1.592 \\
Gate & - & & & 1.090 \\
Funnel & - & & &
\end{tabular}

注) $2 \mathrm{D}:$ 式 (7), Semi-3D : Forcheimer の式, 3D : Richard の 式を表わす。

ここに, $K_{i j}$ :透水係数テンソル, $H$ : 全水頭を表わす. 式 (5)に式 (6) を代入し定常条件を仮定すれば，平面 2 次元飽和定常浸透流方程式が次式により導かれる. なお，水は非圧縮性としている。

$$
\frac{\partial}{\partial x_{i}}\left(K_{i j} \frac{\partial H}{\partial x_{j}}\right)=0
$$

\section{（3）基礎方程式の妥当性}

反応透過壁工法の性能評価を行うための基礎方程 式として式 (7) が妥当であるかを検証するために, 図-5 に示す場に発生する地下水位変化を, 不圧帯 水層での地下水流れを表わす準 3 次元浸透流方程式 (Forcheimerの式 16)）および飽和・不飽和土での地下 水流れを表わす 3 次元浸透流方程式（Richard の式 17)）を使用した解析結果と比較した.

解析空間は図-5に示すように, FGS の対称性を利 用して片半分とした. 地下水流向は $x$ 軸方向で, 動水 勾配 $i=1 / 100$ と仮定し, 解析空間の左端の地下水面 高を $5 \mathrm{~m}$ とした. また, Gate の幅を $2 \mathrm{~m}$, Gate の厚 さを $1 \mathrm{~m}$, Funnel の厚さを $1 \mathrm{~m}$ とした. その他の解析 条件は表-3に示すとおりである. 土の水分特性およ
表-4 初期条件と境界条件

\begin{tabular}{l|ll}
\hline & 初期条件 & \multicolumn{1}{c}{ 境界条件 } \\
\hline \multirow{2}{*}{$2 \mathrm{D}$} & & $\begin{array}{l}H(0, y)=5 \\
H(100, y)=4\end{array}$ \\
\hline \multirow{2}{*}{ Semi-3D } & $H(x, y, 0)=\sqrt{25-0.09 x}$ & $\begin{array}{l}H(0, y, t)=5 \\
H(100, y, t)=4\end{array}$ \\
\hline \multirow{2}{*}{$3 \mathrm{D}$} & \multirow{2}{*}{$H(x, y, z, 0)=\sqrt{25-0.09 x}$} & $\begin{array}{l}H(0, y, z, t)=5 \\
H(100, y, z, t)=4\end{array}$ \\
\hline
\end{tabular}

注） 2D：式 (7), Semi-3D : Forcheimer の式, 3D : Richardの式 を表わす. 表中の単位は $\mathrm{m}$ である.

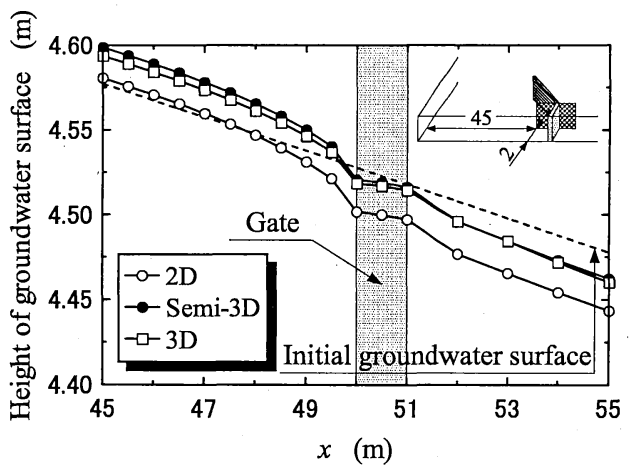

図-6 15 日後の Gate 前背面部における地下水位分布

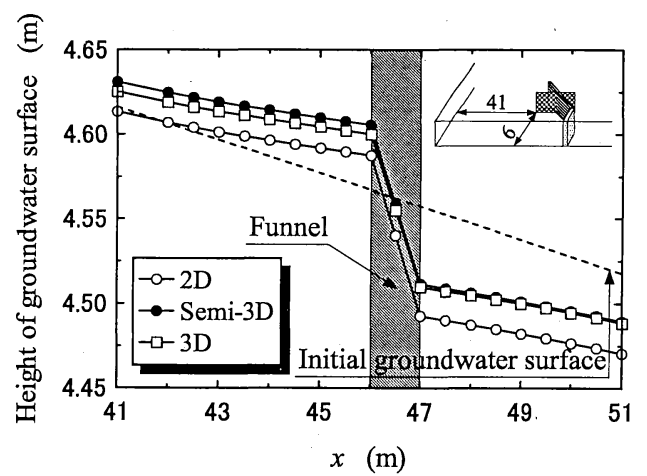

図-7 15 日後の Funnel 前背面部における地下水位分布

び不飽和浸透特性には van Genuchten の提案式 18) を 使用しており, そのパラメータ $\alpha, n$ は, 水分特性曲 線および不飽和浸透特性曲線の形状を決定するパラ メータである 19,20). それぞれの基礎方程式の初期条 件および境界条件を表-4に示す. なお, 初期条件は FGS を設置する前の状態とし, その全水頭は準 3 次 元浸透流方程式 (Forcheimerの式) の定常解を利用し て与えた.

FGS 設置から 15 日後の解析結果を図-6と図-7に 示す. 図-6 は, 解析空間における座標 $x=45, y=$ 2 を通過し $x$ 軸に平行な面, すなわち Gate と Funnel の境界を通過する地下水位分布を表わしたものであ る. 一方, 図-7は, 解析空間における座標 $x=41, y=$ 
6 を通過し $x$ 軸に平行な面, すなわち Funnel 前面部と 背面部の地下水位分布を表わしたものである.なお， 図中の破線はFGS を設置する前の地下水位分布を表 わしている.これらの図から, 予想される地下水面 の形状（勾配）はいずれの基礎方程式を使用しても ほぼ等しく, また, 式(7)から予測される地下水面は 他の基礎方程式から予測される地下水面よりも低い ことが確認できる. 式(7)から予測される地下水面が 他に比べて低い理由として, 式(7)に㹥不圧帯水層に おける水の貯留や水を吸い上げるサクションの影響 が考虑されていないことが挙げられる。,一方で, 水 の貯留の影響を考虑された Forcheimerの式と Richard の式は，ともにほぼ同じ解析結果となっている.

反応透過壁工法の性能評価指標として地下水流速 から評価される浄化性能, 流線から評価される集水 性能を使用するため, 地下水面高よりも地下水面の 形状（動水勾配）が重要となる.いずれの基礎方程 式を使用しても地下水面の勾配はほぼ等しいため, 計算される流速および流線はほぼ等しいと考えられ る. そのため, 反応透過壁工法の性能評価を行うた めの基礎方程式として式 (7) は妥当であると結論付 けた.

\section{（4）性能評価の手法と条件}

式(7)に対して有限要素法を使用してパラメトリッ クスタディを行った. 解析平面図を図-8に示す. 解 析平面は, 前節と同様に, FGS の対称性を利用して 片半分としている. 地下水流向は $x$ 軸方向で, 動水 勾配 $i=1 / 100$ と仮定し, Funnel の厚さを $1 \mathrm{~m}$ とし た. 解析メッシュは解析平面図を幅 $0.1 \sim 5 \mathrm{~m}$ で矩形 分割した（総節点数 30246, 総要素数 29892）. その 他の解析条件は図中に示すとおりである. 境界条件 は, 図-9に示すように, 解析平面の左端および右端 に水位固定型の境界值を与えた. 解析は表-5に示す ように, Gateの幅 $\left(W_{\text {gate }}\right)$, Gateの厚さ $\left(L_{\text {gate }}\right)$, Funnel の幅 $\left(W_{\text {funnel }}\right)$, Gate の透水係数 $\left(k_{\text {gate }}\right)$, Funnel の透水係数 $\left(k_{\text {funnel }}\right)$ をそれぞれパラメトリックに変 化させて行い, Retention Time と Capture Width に対す る依存性を評価した.

FGS の浄化性能を表わす指標 Retention Time は污染
地下水の Gate 内での滞留時間を表わし, 浸透流解析 から得られる Gate 内流速の最大值をもって次式によ り計算する（図-10参照）。

$$
\text { Retention Time }=\underset{0 \leq y^{\prime} \leq W_{\text {gate }}}{\operatorname{Min}}\left(\frac{L_{\text {gate }}}{u_{x}(y /)}\right)
$$

この值が大きいほど, 污染地下水は Gate 内の反応剂 と長時間接触することになり浄化性能は高くなる. Retention Time は周辺地盤透水係数や動水勾配の影響 を受けるため Equivalent Retention Length という指標 をもって標準化する.

$$
\begin{aligned}
& \text { Equivalent Retention Length } \\
& \quad=\text { Retention Time } \times k_{\text {aquifer }} \times i
\end{aligned}
$$

ここに, $k_{\text {aquifer }}$ : 周辺地盤透水係数, $i$ : 動水勾配を表 わす.一方, 集水性能を表わす指標 Capture Width は 污染地下水の捕捉幅を表わし, 浸透流解析より得ら れる流線 21) から次式により計算する（図-11参照）.

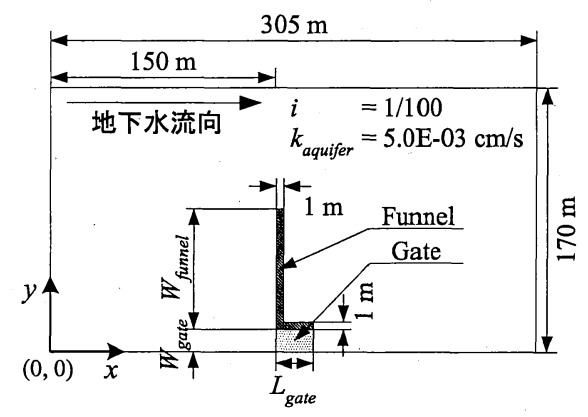

図-8 パラメトリックスタディの解析平面図

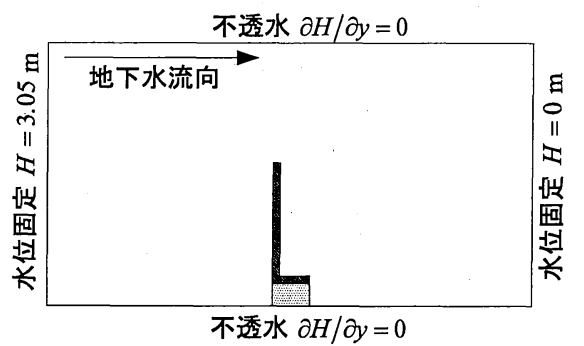

図-9 パラメトリックスタディの境界条件

表-5 パラメトリックスタディの解析条件

\begin{tabular}{l|rrrrr}
\hline & $W_{\text {gate }}(\mathrm{m})$ & $L_{\text {gate }}(\mathrm{m})$ & $W_{\text {funnel }}(\mathrm{m})$ & $k_{\text {gate }} / k_{\text {aquifer }}$ & $k_{\text {funnel }} / k_{\text {aquifer }}$ \\
\hline GW-Series & $0.75 \sim 15$ & 1 & 12 & 10 & 0.001 \\
GL-Series & 6 & $0.1 \sim 1$ & 12 & 10 & 0.001 \\
FW-Series & 6 & 1 & $0 \sim 75$ & 10 & 0.001 \\
GC-Series & 6 & 1 & 12 & $0.1 \sim 1000$ & 0.001 \\
FC-Series & 6 & 1 & 12 & 10 & $0.00001 \sim 0.001$ \\
\hline
\end{tabular}

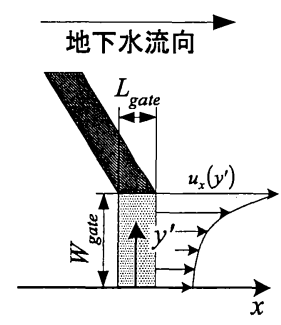

図-10 Retention Time の説明図 


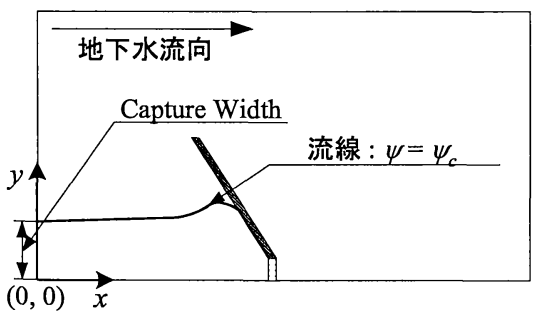

図-11 Capture Width の説明図

$$
\text { Capture Width }=\left.y\right|_{x=0, \psi=\psi_{c}}
$$

ここに, $\psi_{c}$ : Gate と Funnel の境界部における流れ関 数を表わす。

\section{(5) 解析結果}

\section{a) Gate の幅による影響}

GW-Series の解析結果を図-12 に示す. Equivalent Retention Length は Gate 内での地下水流速, すなわち Gate 単位幅あたりの洉染地下水処理量に依存する. そのため, Gate の幅を増加させても Gate 単位幅あた りの污染地下水処理量に著しい影響を与えるとは考 えられないので, Equivalent Retention Length に対する 影響も少ないと考えられる。一方, Capture Width へ の影響は，Gateの幅を増加させると Capture Width に 線形的な増加がみられた。また, その勾配はほぼ 1 に 近いことから Gate の幅がそのまま Capture Width に影 響したと考えられる。

\section{b) Gateの厚さによる影響}

GL-Series の解析結果を図-13に示す. Gateの厚さ を増加させると Equivalent Retention Length に線形的 な増加がみられた．これは, Gate の厚さを増加させ ることによって污染地下水の Gate 内での滞留時間が 増加したためである. 一方, Capture Widthへの影響 はほとんどみられなかった。

\section{c) Funnel の幅による影響}

FW-Series の解析結果を図-14に示す. Funnel の幅 を増加させると Equivalent Retention Length に減少が みられた。これは Funnel の幅の増加に伴い集水範囲 が増加し, Gate 単位幅あたりの污染地下水処理量が 増加したためと考えられる. 一方, Capture Width へ の影響は, Funnel の幅を増加させると Capture Width に線形的な増加がみられた。

\section{d) Gate の透水係数による影響}

GC-Series の解析結果を図-15に示す. 図-15 の横 軸は Gate の透水係数と周辺地盤透水係数の比で定 義している. Equivalent Retention Lengthへの影響は, Gateの透水係数比が 10 以上になるとその影響がほぼ なくなった.これは, Gateの透水係数を増加させても

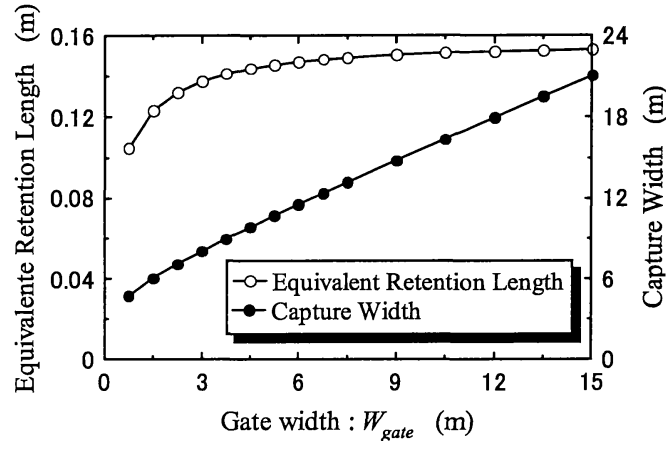

図-12 Gateの幅の影響

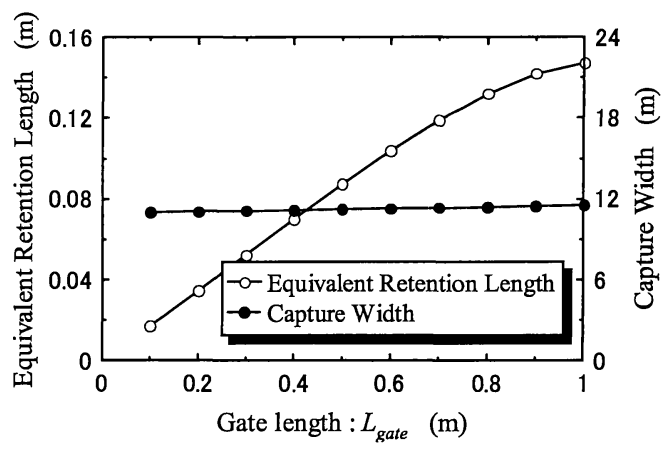

図-13 Gateの愿さの影響

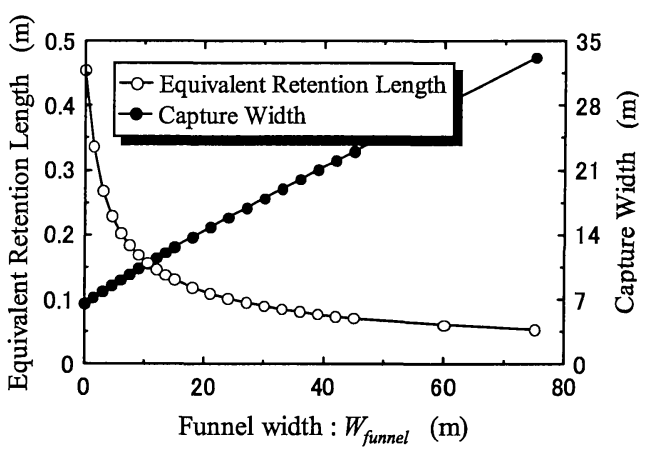

図-14 Funnel の幅の影響

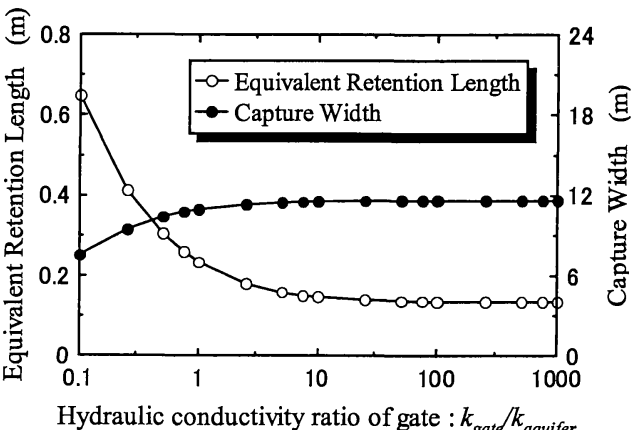

図-15 Gate の透水係数の影響 


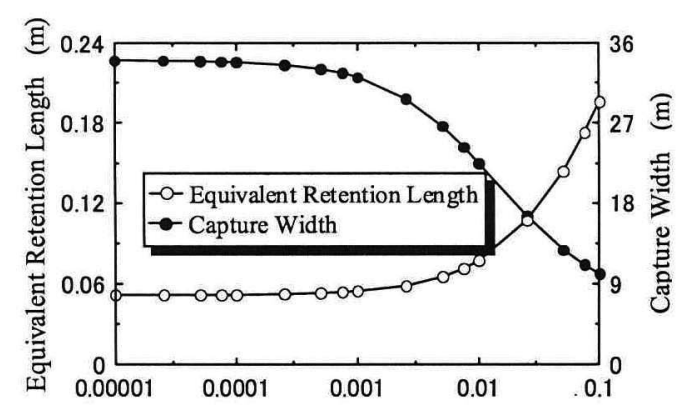

Hydraulic conductivity ratio of funnel $: k_{\text {funnel }} / k_{\text {aquifer }}$

図-16 Funnel の透水係数の影響

表ー6 各設計パラメータを增加させたときの Equivalent Retention Length と Capture Width に対する影響力

\begin{tabular}{l|cc}
\hline & Equivalent Retention Length & Capture Width \\
\hline Gate の幅 & 0 & 0 \\
Gate の厚さ & 0 & $\Delta$ \\
Funnel の幅 & $\Delta$ & $\Delta$ \\
\hline
\end{tabular}

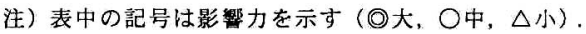

白抜きは增加する影響を，黒塗りは隇少する影響を示す。

Gate 背面の地盤の透水係数が Gate のそれよりも著し く低いために, Gateからの地下水の流出を妨げてい るためと考えられる。一方, Capture Widthへの影響 も Gate の透水係数比が 10 以上になるとその影響は ほとんど現れなくなった。

e) Funnelの透水係数による影響

FC-Series の解析結果を図-16に示す. 図-16の横 軸はFunnelの透水係数と周辺地盤透水係数の比で定 義している. Equivalent Retention Lengthへの影響は, Funnel の透水係数比が 1/1000 以下になるとその影響 がほとんど現れなくなった. 一方, Capture Widthへの 影響も Funnel の透水係数比が $1 / 1000$ 以下になるとそ の影響がほとんど現れなくなった.なお, Equivalent Retention Length と Capture Width に影響を及ぼさない Funnel の透水係数比は Funnel の幅に依存する. Funnel の幅が増加すると Funnel の中央部より污染地下 水が流出する危険性が增えるため, Funnel の幅を長 く施工する際にはより高い遮水性をもった Funnel が 求められる.

\section{（6）透水係数の最適条件}

FGS の設計パラメータに対してパラメトリックス タディを行ったところ, 次のことが明らかになった. Equivalent Retention Length と Caputure Width に対し 対して著しい影響を与える透水係数比で設計を行え ば，施工時の作業や周辺地盤, Gate の不均一性によ
る微小な透水係数の変化により, FGS の性能は大き く変化する. したがって, Gate の透水係数と Funnel の透水倸数は, FGS の浄化性能（Equivalent Retention Length）と集水性能（Capture Width）に及ぼす影響が 少ない次の条件で施工するのが望ましいと考えられ る.

$$
\begin{gathered}
k_{\text {gate }} / k_{\text {aquifer }} \geq 10 \\
k_{\text {funnel }} / k_{\text {aquifer }} \leq 1 / 1000
\end{gathered}
$$

これらの条件を満たすとき, 所要の性能を保持した FGS が施工しやすいと考えられる。このとき，FGS の浄化性能と集水性能は FGS の幾何条件 (Gate の 幅, Gate の厚さ, Funnel の幅）のみに依存する. そ の依存性は図-12〜14 の勾配により評価することが でき，それを表-6に整理した。なお， $k_{\text {aquifer }}$ が小 さい難透水層の場合には地下水流速が小さくなるた め, 污染地下水を浄化するまでに多大な時間を必要 とする.このため, 地下水流れが良好な砂質土程度 の透水係数 $k_{\text {aquifer }}$ をもつ地盤に対して式 (11), 式 (12)を適用することが現実的と考えられる.

式 (11), 式 (12) を満足する条件下では, Equivalent Retention Length と Capture Width は Gate の幅, Gateの 厚さ, Funnel の幅のみに依存するので, 任意関数 $f$, $g$ を使用して次式で与えられる.

$$
\begin{aligned}
& \text { Equivalent Retention Length } \\
& =f\left(W_{\text {gate }}, L_{\text {gate }}, W_{\text {funnel }}\right) \\
& \text { Capture Width }=g\left(W_{\text {gate }}, L_{\text {gate }}, W_{\text {funnel }}\right)
\end{aligned}
$$

任意関数 $f, g$ は图-17, 図-18 に示すような開曲面 を描くような関数となる.なお，図中の E.R.L.とは

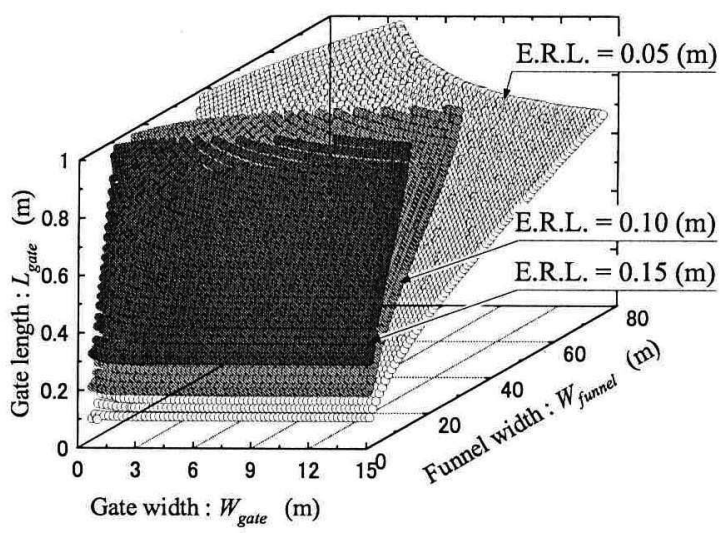

図-17 Equivalent Retention Length（E.R.L.）に対す る FGS 幾何条件の影響 


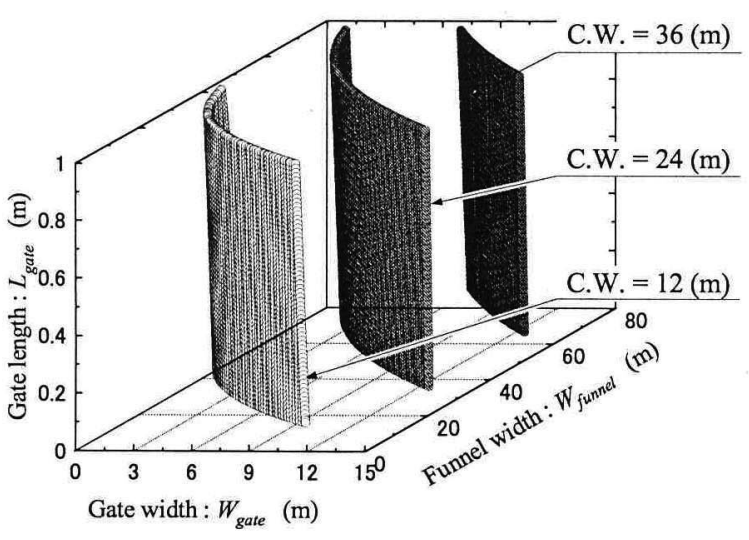

図-18 Capture Width（C.W.）に対する FGS 幾何条 件の影響

Equivalent Retention Length を, C.W. は Capture Width 表わす.この関数の回帰式を導くことは FGS の最適 設計を行う上で有用であると考えられるが，同時に その回帰式の精度も重要となる. 本研究においては 高い精度をもつ回帰式を同定するまでに至っていな いので, 本文で屾図-17, 図-18 構成する数值デー 夕をそのまま FGSの最適設計に使用した。

\section{5. 污染サイト特性に応じた最適設計パラメー 夕の同定}

\section{(1) 概要}

FGS 設計方法の考え方は，Gate へ流入する高濃度 の污染地下水を低濃度まで減衰させる浄化性能をも つこと，そして対象とする污染簌囲を補足する集水 性能をもつことである．污染調查から得られる污染 濃度, 污染範囲から所要の性能を満たす FGS の設計 条件 (Gateの幅, Gate の厚さ, Funnel の幅, 反応剤 充填率) を見出し，その中から最も施工費用が低く なる条件をパラメトリックスタディの結果から検討 した。なお，Gate と Funnel の透水係数は，最適条件 式(11) と式(12)を満足しているものとする.

\section{(2) 最適化問題への定式化}

本文における FGS の設計は，設計パラメータと FGS の性能の関係およびFGS の性能と污染サイト特 性の関係に着目している，その関係を図-19に示す。 図-19 は，污染調查上り得られるサイトの污染濃度 や污染範囲といった情報から，FGS の最適設計パラ メータを取得するまでの流れを示している.'

まず，污染濃度や污染範囲といった情報からその
污染サイトを浄化するのに必要な FGS の浄化性能 と集水性能を検討する。このとき，浄化性能につい ては 3 章で示した Residence Time 以上の Retention Time が必要になり，集水性能については図-20に示 すPlume Width 以上の Capture Width が必要になる. な お, Plume Width とは地下水流向に対して垂直な軸に 関する污染範囲の半分の幅を表わす.

次に，前述のとおりに検討された所要の Retention Time および Capture Width となるような FGS の設計 パラメータ (Gateの幅, Gateの厚さ, Funnelの幅)を, 図-17，図-18 から見出す．所要の Retention Timeお よびCapture Width となるような FGS の設計パラメー 夕の組み合わせは何通りも考えられるため, その中 から最も施工費用が低くなる組を最適設計パラメー タとする。

以上を最適化問題と考え, 目的関数と制約条件式 を定義した。目的関数には，施工費用の最小化を挙 げ次式で定義する.

【Minimize】

$$
\begin{aligned}
\text { Cost index }= & a W_{\text {gate }} L_{\text {gate }}+b W_{\text {funnel }} \\
& +c \phi\left(1-n_{\text {gate }}\right) W_{\text {gate }} L_{\text {gate }} D
\end{aligned}
$$

ここに, Cost index:施工費用を表わす指標， $a$ :所定の 深度までGateを $1 \mathrm{~m}^{2}$ 施工するために必要な費用係数 （反応剂の費用は対象外）, $b$ : 所定の深度まで Funnel を $1 \mathrm{~m}$ 施工するために必要な費用係数（Funnel は層 厚の薄いシートパイルや連続地中壁によって構築さ れることが多いため, Funnel の費用はその幅のみに 依存するものと仮定した),$c$ :反応凨を $1 \mathrm{~m}^{3}$ 含有させ るために必要な費用係数， $D$ : 施工深度を表わす. 制

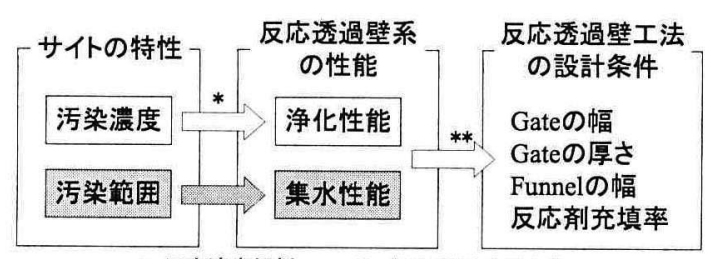

* 反応速度解析 ** 施工費用の最小化

図-19 污染サイト特性から反応透過壁工法の最適設 計条件を求めるまでの主要な流れ

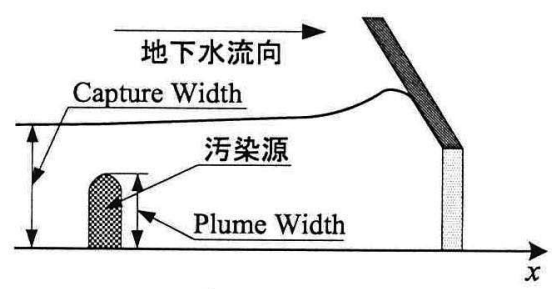

図-20 Capture Width と Plume Width の関係 
約条件式には, 所要の浄化性能と集水性能を満足す ることを挙げ次式で定義する.

【Subject to】

$n_{\text {gate }}$ Retention Time $\geq$ Residence Time

Capture Width $\geq$ Plume Width

式 (16) は, FGS が污染地下水を浄化することのでき る浄化性能をもつための式である.この式が満足さ れないと, 污染地下水が所定の浄化目標濃度にまで 減衰されないまま Gateを通過してしまう. なお, Retention Time はダルシー流速により評価しているた め，実流速で評価するために Gate の（有効）間隙率 $n_{\text {gate }}$ を掛けている. 一方, 式 (17) は, FGS が污染地 下水を集水することのできる集水性能をもつための 式である.この式が満足されないと，污染地下水は Gateへ導かれずに Funnel 側方より流出してしまう.
Residence Time は表-2 に示すとおり $\phi$ の関数であり， Retention Time (Equvalent Retention Length) と Capture Width は式(13), 式(14)が示すとおり $W_{\text {gate }}, L_{\text {gate }}$, $W_{\text {funnel }}$ の関数である. したがって, 式(15) (17) 中の 変数は設計パラメータである $W_{\text {gate }}, L_{\text {gate }}, W_{\text {funnel }}, \phi$ の 4 つとなる.

\section{(3) 最適化問題の解法例}

式 (15) (17) からなる最適化問題を解けば, 最 小の施工費用を与える最適解（最適設計パラメー 夕）が得られる. 計算方法には, 各変数 $W_{\text {gate }}, L_{\text {gate }}$, $W_{\text {funnel }}, \phi$ にある仮定した值を順次パラメトリック に変化させて代入し，制約条件式を満たし，なおか つ目的関数の最小值を与えたときの変数値を最適値 とする方法を使用した．最適解を求めるまでの流れ 図を図-21に示す.

図-21 は, ある仮定した $W_{\text {gate }}^{(i)}, L_{\text {gate }}^{(j)}, W_{\text {funnel }}^{(k)}, \phi^{(l)}$

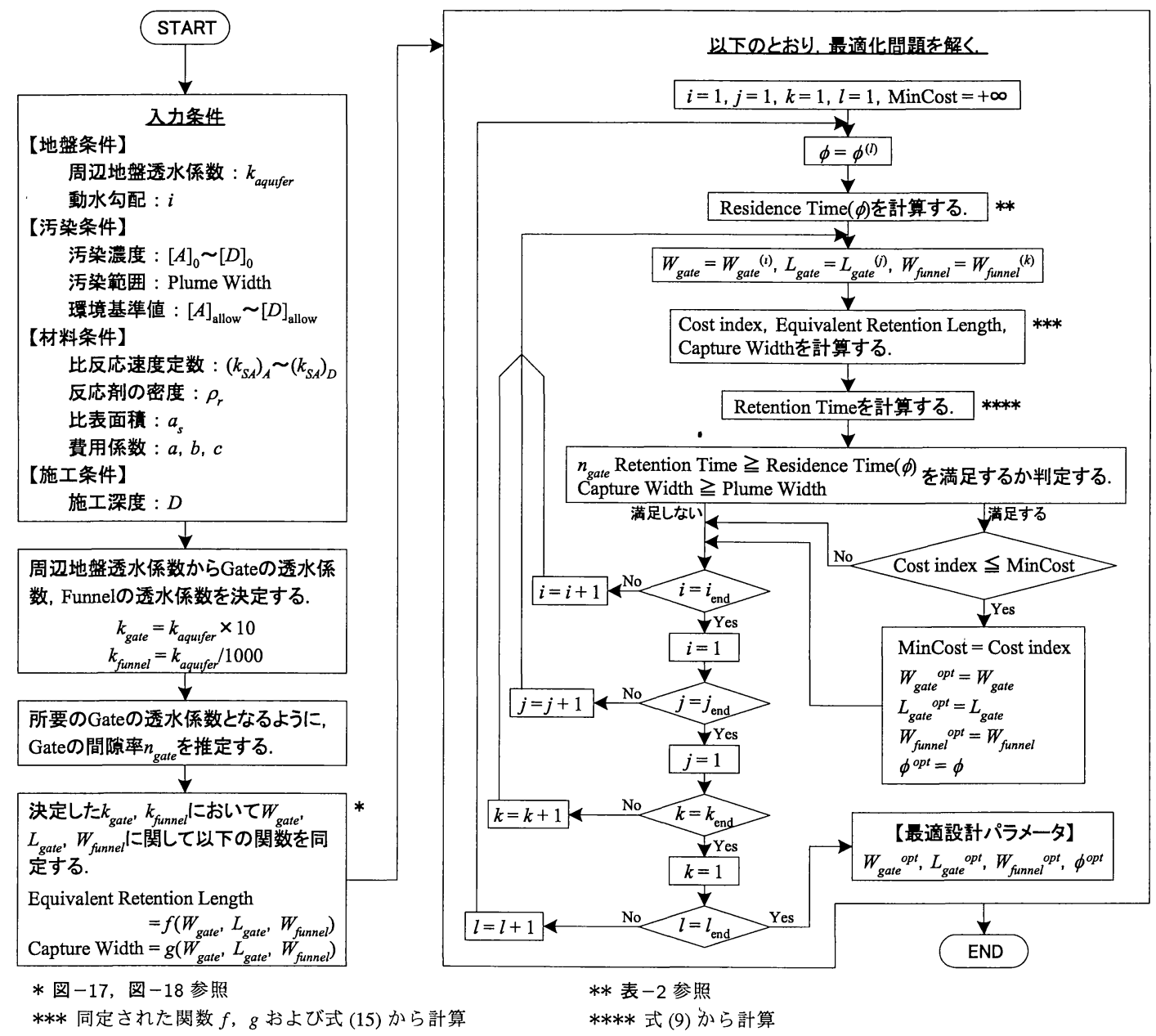

図-21 最適化問題の解法例 
に対して,

(1) 反応速度解析を行い, Residence Time $\left(\phi^{(1)}\right)$ を計 算する。

(2) 目的関数である式 $(15)$ に $W_{g a t e}^{(i)} \sim \phi^{(l)}$ を代入し, Cost index $\left(W_{\text {gate }}^{(i)}, L_{\text {gate }}^{(j)}, W_{\text {funnel }}^{(k)}, \phi^{(l)}\right)$ を計算する.

(3) 浸透流解析を行い, Equivalent Retention Length $\left(W_{\text {gate }}^{(i)}, L_{\text {gate }}^{(j)}, W_{\text {funnel }}^{(k)}\right) \subset$ Capture Width $\left(W_{\text {gate }}^{(i)}, L_{\text {gate }}^{(j)}\right.$, $\left.W_{\text {funnel }}^{(k)}\right)$ を計算する.

（4）式 (9) を使用して, 計算された Equivalent Retention Length を Retention Timeに変換する.

（5）制約条件式（式(16)および式(17)）を満足するか 判定する.

(6) (5) での制約条件式を満足し，(2) で計算された Cost index がこれまで計算された Cost index よ りも小さいならば, $W_{\text {gate }}^{\text {opt }}=W_{\text {gate }}^{(i)}, L_{\text {gate }}^{\text {opt }}=L_{\text {gate }}^{(j)}$, $W_{\text {funnel }}^{\text {opt }}=W_{\text {funnel }}^{(k)}, \phi^{o p t}=\phi^{(l)}$ と值を更新する.

を行い, 仮定する值 $W_{\text {gate }}^{(i)}, L_{\text {gate }}^{(j)}, W_{\text {funnel }}^{(k)}, \phi^{(l)}$ を順 次連続的に変化させ, 上記の項目を繰り返すもので ある.なお, $W_{\text {gate }}^{(i)}, L_{\text {gate }}^{(j)}, W_{\text {funnel }}^{(k)}, \phi^{(l)}$ はパラメトリ ックに仮定される值を表わす. $i$ 〜 はそれぞれ $W_{\text {gate }}$, $L_{\text {gate }}, W_{\text {funnel }}, \phi$ の標本点を表わし, $i$ は 1 から $i_{\text {end }}$ ま で, $j$ は 1 から $j_{\text {end }}$ まで, $k$ は 1 から $k_{\text {end }}$ まで, $l$ は 1 から $l_{\text {end }}$ まで動く. 例えば, $1 \leq i \leq 5$ の場合, $W_{\text {gate }}$ は 5 ケース, パラメトリックに変化させている. $i_{\text {end }}$ 〜 $l_{\text {end }}$ はそれぞれの総標本数を表わす.

この方法における最適解の保証は, 仮定する変数 值 $W_{\text {gate }}, L_{\text {gate }}, W_{\text {funnel }}, \phi$ の定義域に依存する. 定 義域が狭ければ, 真の最適解が定義域外にある可能 性があり，最適性を保証することはできない。この とき, 計算から得られる 4 つの最適解 $W_{\text {gate }}^{\text {opt }}, L_{\text {gate }}^{\text {opt }}$, $W_{\text {funnel }}^{\text {opt }}, \phi^{o p t}$ のうち少なくとも 1 つ, その定義域の 境界值で得られる.このように, 最適解の保証が得 られない場合には, 各変数の定義域を広くする, も しくは適切な計算条件に変更する（例えば, 污染濃 度や污染範囲を小さくする）必要がある。

\section{(4) 計算条件}

計算条件を表-7に示す. FGS の最適設計において 対象とする污染サイトには, 污染物質 PCE が 10〜 $1000 \mathrm{mg} / \mathrm{L}$ 存在し, その污染範囲が 5〜 $15 \mathrm{~m}$ であ ると仮定した。各污染物質の浄化目標値には, 各環 境基準值を設定した. なお， VCには環境基準值が定 められていないため, 本計算においては $0.04 \mathrm{mg} / \mathrm{L}$ とした. 費用係数 $a, b$ については, Gate と Funnel を施工するために必要な費用は同じであると仮定し た. Funnel の施工費用については, 柱列式連続壁工 法を想定し, この工法における $1 \mathrm{~m}^{2}$ あたりの施工費
表 -7 最適化問題の計算条件

\begin{tabular}{|c|c|c|}
\hline & 単位 & 值 \\
\hline 周辺地盤透水係数 : $k_{\text {aquifer }}$ & $\mathrm{cm} / \mathrm{s}$ & $5.0 \times 10^{-3}$ \\
\hline 動水勾配: $i$ & - & $1 / 100$ \\
\hline Gate の間隙率 : $n_{\text {gate }}$ & - & 0.45 \\
\hline 反応剤の密度 $: \rho_{r}$ & $\mathrm{~g} / \mathrm{m}^{3}$ & $6.8 \times 10^{6}$ \\
\hline 反応剤の比表面積 : $a_{s}$ & $\mathrm{~m}^{2} / \mathrm{g}$ & 0.10 \\
\hline 反応速度定数 : $\left(k_{S A}\right)_{A}$ & $\mathrm{~m} /$ day & $5.04 \times 10^{-2}$ \\
\hline$:\left(k_{S A}\right)_{B}$ & $\mathrm{~m} /$ day & $9.36 \times 10^{-3}$ \\
\hline$:\left(k_{S A}\right)_{C}$ & $\mathrm{~m} /$ day & $9.84 \times 10^{-4}$ \\
\hline$:\left(k_{S A}\right)_{D}$ & $\mathrm{~m} /$ day & $1.20 \times 10^{-3}$ \\
\hline 施工深度 : $D$ & $\mathrm{~m}$ & 6 \\
\hline 浄化目標值 : $[A]_{\text {allow }}$ & $\mathrm{mg} / \mathrm{L}$ & 0.01 \\
\hline$:[B]_{\text {allow }}$ & $\mathrm{mg} / \mathrm{L}$ & 0.03 \\
\hline$:[C]_{\text {allow }}$ & $\mathrm{mg} / \mathrm{L}$ & 0.04 \\
\hline$:[D]_{\text {allow }}$ & $\mathrm{mg} / \mathrm{L}$ & 0.04 \\
\hline Gate の費用係数 : $a$ & $1 / \mathrm{m}^{2}$ & 1 \\
\hline Funnel の費用係数: $b$ & $1 / \mathrm{m}^{2}$ & 1 \\
\hline 反応剤の費用係数: $c$ & $1 / \mathrm{m}^{2}$ & 600 \\
\hline 初期污染濃度 : $[A]_{0}$ & $\mathrm{mg} / \mathrm{L}$ & $10 \sim 1000$ \\
\hline$:[B]_{0}$ & $\mathrm{mg} / \mathrm{L}$ & 0 \\
\hline$:[C]_{0}$ & $\mathrm{mg} / \mathrm{L}$ & 0 \\
\hline$:[D]_{0}$ & $\mathrm{mg} / \mathrm{L}$ & 0 \\
\hline 污染範囲 : Plume Width & $\mathrm{m}$ & $5 \sim 15$ \\
\hline
\end{tabular}

注) $A:$ PCE, $B:$ TCE, $C:$ cis-1,2-DCE, $D: \mathrm{VC}$ を表わす.

用 9,000〜 12,000 円を参考とした（H 鋼なし）. 費用 係数 $c$ については，市販されている鉄粉 $5 \mathrm{~kg}$ あたり の費用 4,400円を参考とした（同和鉄粉）. 以上から, 費用係数 $a \sim_{c}$ の間には, おおむね $a: b: c=1: 1: 600$ という比が算出される.

最適化問題における制約条件式中の FGS の性能 を表わす Equivalent Retention Length および Capture Width については, 4 章での解析結果である図-17, 図-18をそのまま使用した。なお, 本計算における 各変数の定義域は $0.75 \mathrm{~m} \leq W_{\text {gate }} \leq 15 \mathrm{~m}, 0.1 \mathrm{~m} \leq$ $L_{\text {gate }} \leq 1 \mathrm{~m}, 0 \mathrm{~m} \leq W_{\text {funnel }} \leq 75 \mathrm{~m}, 1 \% \leq \phi \leq 100$ \%である. 最適解は, この定義域内で得られる.

\section{(5) 計算結果}

計算結果を図-22, 図-23に示す. 図-22 は污染範 囲 Plume Width $=5 \mathrm{~m}$ と固定した場合に, サイト の污染濃度の大きさによって FGS の最適設計パラ メータがどのように変化するのかを表わしたもので ある.その結果, いずれの污染濃度においても FGS 設計パラメータの最適值はほぼ同じとなった。サイ トの污染濃度が変われば, 特に Gateの厚さと反応剂 充填率に影響を与えると考えられるが，いずれの洉 染濃度においても実際に施工できないほど非常に小 さい值 $L_{\text {gate }}^{o p t}=0.1 \mathrm{~m}, \phi^{o p t}=2 \%$ 近傍となった. 一方, 図 -23 は污染濃度 $[A]_{0}=10 \mathrm{mg} / \mathrm{L}$ と固定した場合に, サ イトの污染範囲の大きさによって FGS の最適設計パ 


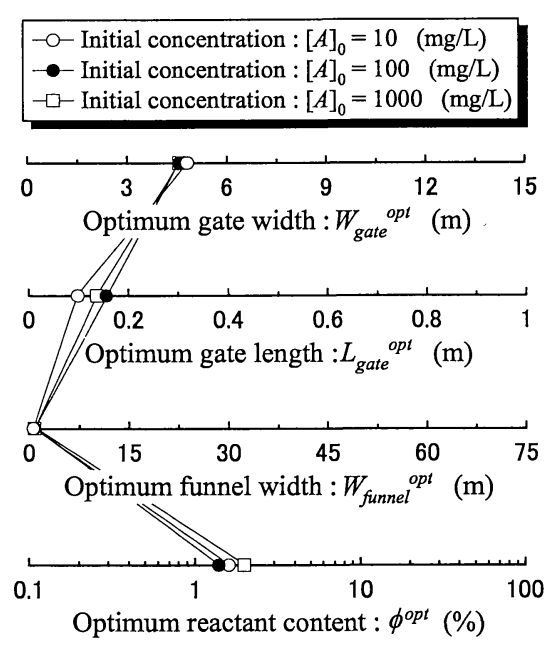

図-22 污染浱度による最適值への影響

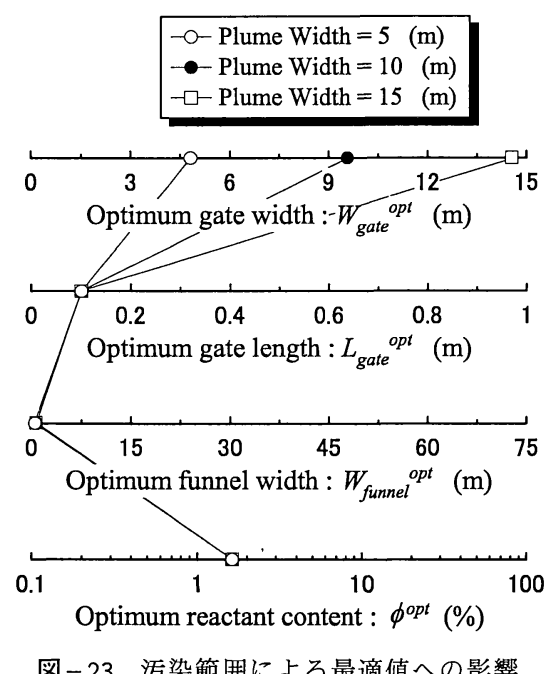

図-23污染範囲による最適值への影響

ラメータがどのように変化するのかを表わしたもの である. その結果, 污染範囲が変われば, Gateの幅の みに著しい影響を与えた。本計算においていずれの 場合も $W_{f u n n e l}^{\text {opt }}=0 \mathrm{~m}$ 近傍であったため, Funnel 設置の 有効性が確認されなかった. Funnel 設置の有効性は Gate と Funnel の施工費用に依存し, Gate の施工費用 が大きくなるにつれて Funnel 設置の有効性が向上す ると考えられる，Gate の施工費用は反応剂の量に大 きく依存し，それは反応剂充填率と Gate の体積（施 工深度, Gate の幅, Gate の厚さ) に依存する. 本計算 は実施工に適さないほど小さな Gate の厚さおよび反 応剂充填率も計算の対象としたため, Gate の施工費 用が小さく見積もられてしまい Funnel設置 (FGS) の 有効性が確認されなかったものと考えられる.なお， いずれの計算でも, 最適な反応剂充填率は $2 \%$ (反応
剂と土を 2：98 で配合）近傍となっており，それだ けの反応剂を充填させて Gateを施工すれば污染物質 を浄化できることを示唆している. しかし，この值 は，実務上施工が難しいほどの小さな值となってい る.このような結果に至った理由の 1 つとして，3章 で述べた污染地下水と反応剂の接触確率を無視して いることに起因する.

\section{(6) 考察}

実際の施工条件を考えれば，Gate の構造安定性確 保の点から Gate の厚さは $1 \mathrm{~m}$ 以上, また土粒子と反 応剂の均一的混合のために反応剂充填率は $20 \%$ 以上 必要と考えられる ${ }^{2)}$ が, これらの条件を無視し最適 化問題を解いたところ, Gate の厚さと反応剂充填率 の最適值は実施工に適さないほど小さい值となった. したがって, 本計算によって得られた值 $L_{\text {gate }}^{o p t}=0.1 \mathrm{~m}$, $\phi^{o p t}=2 \%$ 以上の条件で設計される FGS は, 浄化性 能に対して十分に安全側に設計されていると考えら れる。

現場での施工条件を考虑した場合に FGS の最適設 計パラメータがどのように変化するのかを再検討す るために, Gateの厚さを $1 \mathrm{~m}$, 反応剂充填率を $20 \%$ と 固定させて再度計算を行った. 計算条件は表-7 と同 じである，その計算結果を図-24, 図-25に示す，図 -24 は, 污染範囲 Plume Width $=5 \mathrm{~m}$, Gate の厚さ を $1 \mathrm{~m}$, 反応剂充填率を $20 \%$ と固定した場合におけ る, サイトの污染濃度による Gate の幅と Funnel の幅 の最適值の変化を表わしたものである.いずれの污 染濃度においてもそれらの最適值は全く同じであっ た。これは, Gate の幅と Funnel の幅に与える影響が 大きい要因は污染範囲であり, 污染濃度がそ机らに 与える影響は小さいためである。 また, 最適な Funnel の幅が $13 \mathrm{~m}$ と Funnel 設置の有効性が確認された. 最適な Gate の幅については, 本計算では $0.75 \mathrm{~m}$ と 計算されたがこの值は Gate の幅の定義域の最小の值 であるため, 実際には $0.75 \mathrm{~m}$ よりも小さい值が計算 される可能性がある. 図一 25 は, 污染濃度 $[A]_{0}=10$ $\mathrm{mg} / \mathrm{L}$, Gate の厚さを $1 \mathrm{~m}$, 反応剂充填率を $20 \%$ と固 定した場合における，サイトの污染範囲による Gate の幅と Funnel の幅の最適值の変化を表わしたもので ある，污染範囲が増加するにつれて，それを集水さ せるために必要な Funnel の幅も増加している. Gate の施工費用に関わるパラメータ（費用係数 $a, c$, 施 工深度 $D$ ) が著しく低い場合には, Funnel の幅を増加 するよりも, Gate の幅を増加する方が有益となる場 合がある.この場合においては, Funnel を設置しな い工法が有効となる.

以上のことを整理すると, FGS の最適設計を行う 


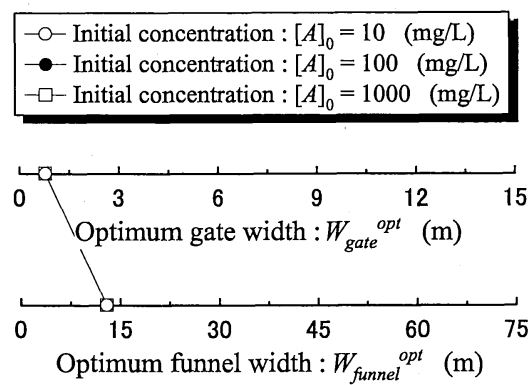

図-24 Gate の幅を $1 \mathrm{~m}$, 反応剂充填率を $20 \%$ とした 場合における污染濃度による最適值への影響

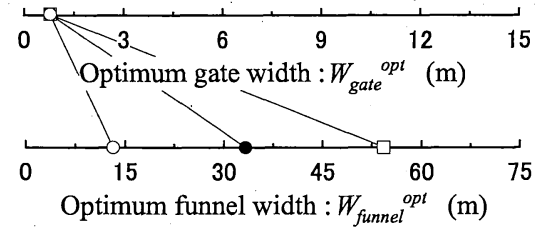

図-25 Gate の幅を $1 \mathrm{~m}$ ，反応剂充填率を $20 \%$ とした 場合における污染篹囲による最適值への影響

上で重要となるパラメー夕は, Gate の幅と Funnel の 幅の 2 つのみとなる.つまり, 所要の集水性能をも つ FGS の設計法が最適設計法につながると考えられ る.なお, Gateの厚さと反応剂充填率については, そ の最適值は非常に小さいため, 現場の施工条件に合 わせて決定すればよい.

\section{(7) FGS の最適設計法の提案}

これまでの最適化問題の計算結果から, FGS の最 適設計法を提案する. FGS の最適設計法は, FGS の 設計パラメータと考えられる Gateの幅, Gateの厚さ, Funnel の幅, 反応剂充填率の 4 つの最適值を求める ことを目的とするが, 前節における計算結果を考慮 すれば，4つの設計パラメータのうち Gate の厚さと 反応剂充填率は施工条件によって決定される可能性 が高いと考えられる，そこで, Gate の厚さと反応剂 充填率は入力条件と考え, 残る 2 つ設計パラメー 夕である Gate の幅と Funnel の幅の最適値を求める設 計法を提案することとした.

FGS を設計する上で必ず満足しなければならない 条件は，式 (16) および式 (17) である。 それぞれの制 約条件式は次のように書き換えることができる．ま ず, Retention Time が式 (8)、で評価されることに注意

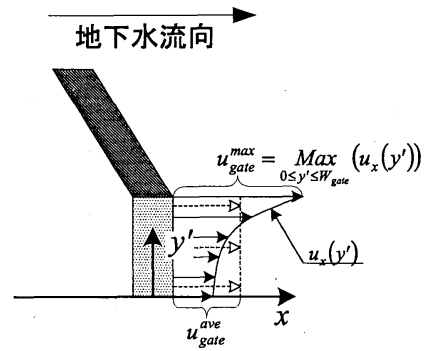

図-26最大地下水流速と平均地下水流速の説明図

して式(16)を次のように書き換える.

$$
n_{\text {gate }} \cdot \frac{L_{\text {gate }}^{c}}{\alpha \cdot u_{\text {gate }}^{\text {ave }}} \geq \text { Residence Time }\left(\phi^{c}\right)
$$

ここに， $\alpha$ :Gateを通過する平均地下水流速に対する 修正係数, $u_{\text {gate }}^{\text {ave }}$ : Gate を通過する平均地下水流速（ダ ルシー流速), $L_{\text {gate }}^{c}$ : Gate の構造安定性等の施工条件 から必要とされる最小の Gateの厚さ, $\phi^{c}$ : 反応剂を均 一に含有させた Gate を施工するために必要な最小の 反応剂充填率を表わす. 修正係数 $\alpha$ は図-26に示す ように, Gateを通過する最大地下水流速と Gate を通 過する平均地下水流速の比を表わし, 通常 $\alpha \geq 1$ と なる.修正係数の值を図-27に示す. 図-27 は 4 章で 示した浸透流解析により評価され，図-8 と同じ解析 平面図において $W_{\text {gate }}=1.5 \mathrm{~m}, L_{\text {gate }}=1 \mathrm{~m}, k_{\text {gate }} / k_{\text {aquifer }}$ $=10, k_{\text {funnel }} / k_{\text {aquifer }}=1 / 1000$ の条件のもと $W_{\text {funnel }}$ を パラメトリックに変化させ修正係数 $\alpha$ の変化を調べ ている. この図から, 修正係数 $\alpha$ の值として $\alpha=2$ が 妥当と考えられる。ま, Gate の厚さ $L_{\text {gate }}^{c}$ は Gate を 施工する機械の性能に依存すると考えられるが， あ まり薄い層厚の Gateを施工することは困難であるこ とから $L_{\text {gate }}^{c}=1 \mathrm{~m}$ 程度が妥当と考えられる. 反応 剂充填率 $\phi^{c}$ は Gate の施工方法や施工条件に依存す ると考えられるが, 過去の実験等 ${ }^{2)}$ を参考にすれば, $\phi^{c} \geq 20 \%$ 程度が妥当と考えられる. 次に, 式 (17)に ついて考える. 式 (17) が満足することは, 図-28に おける Gate 部と污染領域部において次式に示す連続 式が満足することと同值である，なお，污染領域は FGS の設置による流況変化が及ばないほど，遠方の 位置にあるものとする.

$$
W_{\text {gate }} \cdot u_{\text {gate }}^{\text {ave }} \geq \text { Plume Width } \cdot u_{\text {aquifer }}
$$

ここに, $u_{\text {aquifer }}$ : 周辺地盤を流れる地下水流速（ダル シー流速）を表わすものとする.ここで, 式(18)およ び式(19)から次式が導かれれる.

$$
\frac{W_{\text {gate }}}{\text { Plume Width }} \geq \frac{\alpha \cdot u_{\text {aquifer }} \cdot \text { Residence Time }\left(\phi^{c}\right)}{n_{\text {gate }} \cdot L_{\text {gate }}^{c}}
$$




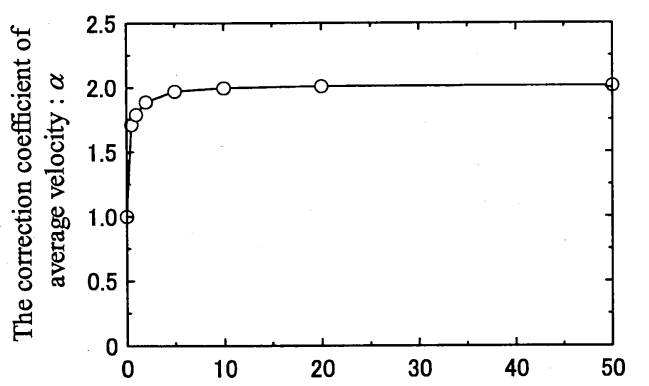

The ratio of funnel width and gate width : $W_{\text {funnel }} / W_{\text {gate }}$

図-27 修正係数 $\alpha$ と FGS 幾何条件（Funnel の幅と Gate の幅）の影響

式 (20) の左辺は, 污染範囲に対してどこまで Gate の 幅を縮小できるかを表わすものである. 一方, 右辺 はすべて地盤調查および施工条件によって決まるも のであり既知量となりうる.ここで, 式 (20) の右辺 を次のように定義する.

$$
U \equiv \frac{\alpha \cdot u_{\text {aquifer }} \cdot \text { Residence Time }\left(\phi^{c}\right)}{n_{\text {gate }} \cdot L_{\text {gate }}^{c}}
$$

ここに, $U:$ 污染調查や施工条件により決定される 無次元パラメータを表わす. 例えば, サイトの地盤 調查を行えば, そのサイトを流れる地下水の流速 $u_{\text {aquifer }}$ が得られる. また, Gate に使用する材料が決 まれば, その大きさ（粒径）から Gate の間隙率 $n_{\text {gate }}$ を推測できる.さらに, 污染調査から污染濃度, 現 場での施工条件等から反応剂を均一に含有させた Gate を施工するために必要な最小の反応剂充填率 $\phi^{c}$, Gate の構造安定性から必要とされる最小の Gate の厚さ $L_{\text {gate }}^{c}$ が得られ, 3 章に示した反応速度解析か $ら$ Residence Time $\left(\phi^{c}\right)$ も計算される.

式 (20) が満足することは, FGS の設計における 制約条件（式 (16)，式 (17)）を満足することである. したがって, サイトの調査や施工条件が把握できれ ば, 無次元パラメータU が決定され, 式 (20) から 所要の性能をもつ FGS を設計するための Gate の幅 に関する条件が得られる。なお， $U$ が 1 以上ならば $W_{\text {gate }} /$ Plume Width が 1 以上（ちょうど図-28の状態） であるため, Funnel を使用しない Continuous PRB 工 法が有効となる. Coninuous PRB 工法の設計方法につ いては, 米国の環境保護庁 (EPA) の資料 ${ }^{2)}$ に詳述さ れている. 流況に影響を与える Funnel を設置しない ため, 污染領域の鉛直断面積と同等 $\left(W_{\text {gate }}=\right.$ Plume Width）の Gate を施工すればよい.

実際, 地下水流速や Residence Timeの值は小さいの で, $U$ の值が 1 以下になる場合がほとんごである. $U$
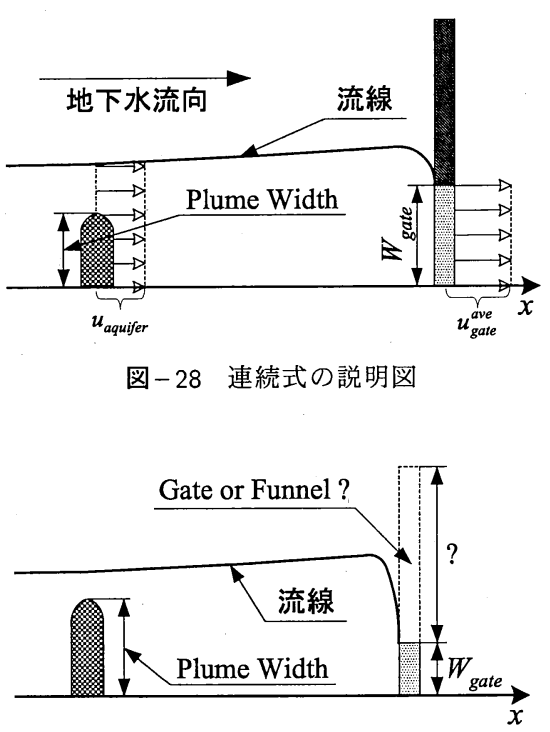

図-29 $W_{\text {gate }} /$ Plume Width $\leq 1$ の状態

の值が 1 以下, すなわち $W_{\text {gate }} /$ Plume Widthが 1 以下の 状態を図-29に示す. 式 (20)により Gate の幅に関す る条件が得られるので, その条件から Gate の幅およ びFunnelの幅を決定することになる.つまり, 図-29 における破線の部分を Gate またはFunnel で施工する かを判断し, 各々の幅を決定することになる.

図-29における破線の部分をGateで施工するのか, Funnel で施工するのかの判断は, 各々の単位幅あた りの施工費用から決定される. Gate の単位幅あたり の施工費用は, 式(15)に対して $W_{\text {gate }}$ で偏微分（テイ ラー展開）すれば次式のように計算される.

$$
(\text { Cost index })_{\mathrm{GW}}=a L_{\text {gate }}+c \phi^{c}\left(1-n_{\text {gate }}\right) L_{\text {gate }}^{c} D
$$

ここに, $(\text { Cost index })_{\mathrm{GW}}$ : Gate の単位幅あたりの施工 費用を表わす. Funnel の単位幅あたりの施工費用も 同様に, 次式のように計算される.

$$
(\text { Cost index })_{\mathrm{FW}}=b
$$

ここに, $(\text { Cost index })_{\mathrm{FW}}$ :Funnel の単位幅あたりの施工 費用を表わす. 式 (22) および式 (23) から計算される 施工費用の大小から, 図-29における破線の部分を Gate で施工するのか Funnel で施工するのかを判断す る.一般に, 式 (22)の右辺第 2 項目（反応剂の費用） の値が大きくなるため, 式 (23) から計算される施工 費用の方が小さくなる.したがって, 図-29における 破線の部分はFunnel で施工した方が有利になる. 仮 に, 式 (22) から計算される施工費用の方が小さいな らば, Funnel を設置せずに $W_{\text {gate }}=$ Plume Width となる ような Gate を施工した方が有利になる（Continuous 
PRB 工法) .

Funnel（FGS工法）を使用した方が有利と判断され た場合には, 図-29に示す流線を描けるような Funnel の幅を決定する必要がある. つまり, 所要の Capture Width が得られるような Funnel の幅を決定する 必要がある. Capture Width と Funnel の幅の関係は図 -18 に示される. 図-18を図-30 のように, 縦軸に $W_{\text {gate }} /$ Capture Width, 横軸に $W_{\text {funnel }} / W_{\text {gate }}$ と再整理す ると, 強い相関関係が認められた。これは， $L_{\text {gate }}=1$ $\mathrm{m}$ の場合であるが, Capture Width に対する $L_{\text {gate }}$ の依 存性は図-18 からほとんどみられないため, 図-30 の関係はいかなる $L_{\text {gate }}$ においても成り立つと考えて よい．また，この回帰式は次式で与えられる。

$$
\begin{aligned}
\frac{W_{\text {funnel }}}{W_{\text {gate }}}=[ & a_{1}\left(\frac{W_{\text {gate }}}{\text { Capture Width }}-1\right)+ \\
& a_{2}\left(\frac{W_{\text {gate }}}{\text { Capture Width }}-1\right)^{2}+ \\
& \left.a_{3}\left(\frac{W_{\text {gate }}}{\text { Capture Width }}-1\right)^{3}\right] \cdot \frac{\text { Capture Width }}{W_{\text {gate }}}
\end{aligned}
$$

ここに, $a_{1}=-4.2472, a_{2}=-8.4006, a_{3}=-8.2714$ である，この関係は，透水係数の最適条件である式 (11), 式 (12) を満足していれば，いかなる FGS の形 状に対しても成り立つと考えてよい，また，Capture Width には式 (17) で示される制約条件式が課せられ ている. 式(17) を次のように変形する.

$$
\frac{W_{\text {funnel }}}{\text { Plume Width }} \geq \frac{W_{\text {gate }}}{\text { Capture Width }} \cdot \frac{W_{\text {funnel }}}{W_{\text {gate }}}
$$

式 (25) に式 (24) を代入すると, 所要の性能をもつ FGS を設計するための Funnel の幅に関する条件が得 られる。

$$
\begin{aligned}
\frac{W_{\text {funnel }}}{\text { Plume Width }} \geq & a_{1}\left(\frac{W_{\text {gate }}}{\text { Capture Width }}-1\right)+ \\
& a_{2}\left(\frac{W_{\text {gate }}}{\text { Capture Width }}-1\right)^{2}+ \\
& a_{3}\left(\frac{W_{\text {gate }}}{\text { Capture Width }}-1\right)^{3}
\end{aligned}
$$

式 (20) と式 (26) を同時に満たす Gate の幅と Funnel の幅で設計すれば, 所要の性能を満足した FGSが設 計される.また, FGS の最小施工費用を与える最適 な Gate の幅および Funnel の幅は, 制約条件式の等号 成立時に与えられる.このとき Capture Width = Plume Width であるから, 最適な Gate の幅および Funnel の 幅は式 (20), 式 (26) から次式のように決定される.

$$
\begin{gathered}
W_{\text {gate }}^{\text {opt }}=\text { Plume Width } \cdot U \\
W_{\text {funnel }}^{\text {opt }}=\text { Plume Width } \cdot \sum_{n=1}^{3} a_{n}(U-1)^{n}
\end{gathered}
$$
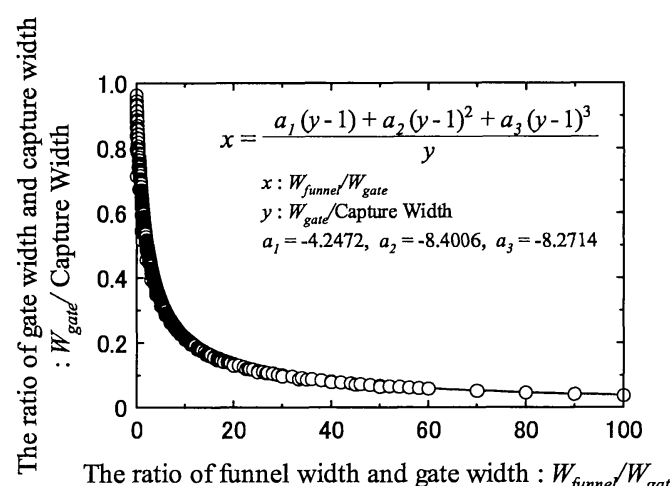

The ratio of funnel width and gate width : $W_{\text {funnel }} / W_{\text {gate }}$

図-30 Gateの幅により無次元化された Capture Width と Funnel の幅の関係

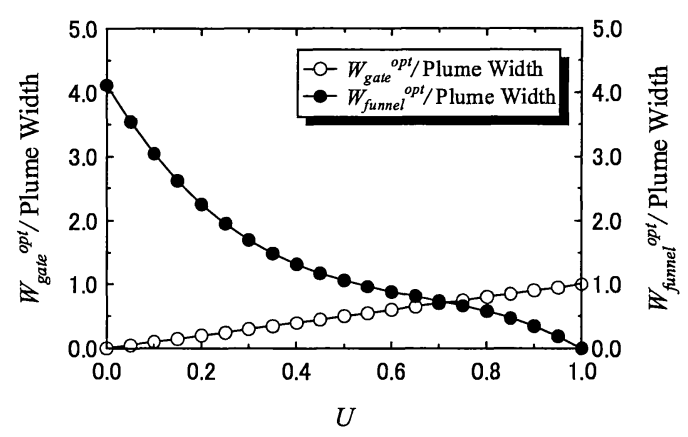

図-31 無次元パラメータ $U$ と最適な Gate の幅 $W_{\text {gate }}^{\text {opt }}$, 最適な Funnel の幅 $W_{\text {funnel }}^{\text {opt }}$ の関係

ここに, $a_{1}=-4.2472, a_{2}=-8.4006, a_{3}=-8.2714$ であり，U は式 (21)により定義される污染調査や施 工条件によって決定される無次元パラメータである. 図-31に無次元パラメータ $U$ と $W_{\text {gate }}^{o p t}, W_{\text {funnel }}^{\text {opt }}$ の関 係を示す. なお, $U=1$ のとき, $W_{\text {gate }}^{o p t}=$ Plume Width, $W_{\text {funnel }}^{\text {opt }}=0$ となり, Continuous PRB 工法の設計条件と なる. 本節の内容を整理し, 提案した FGS の最適設 計法の流れ図を図-32に示す。

\section{6. 結論}

反応透過壁工法の最適な材料条件・形状条件（設 計パラメータ）を決定するため, 設計パラメータと 性能の関係を浸透流解析により明らかにし, 性能と 污染サイト特性の関係を反応速度解析により検討し た. その結果, 以下のことが結論付けられた.

(1) 污染地下水を反応剂 (零価鉄粉) により所定の 濃度まで減衰させるのに必要な時間を反応速度 解析により評価した。その結果, 反応剂充填率 


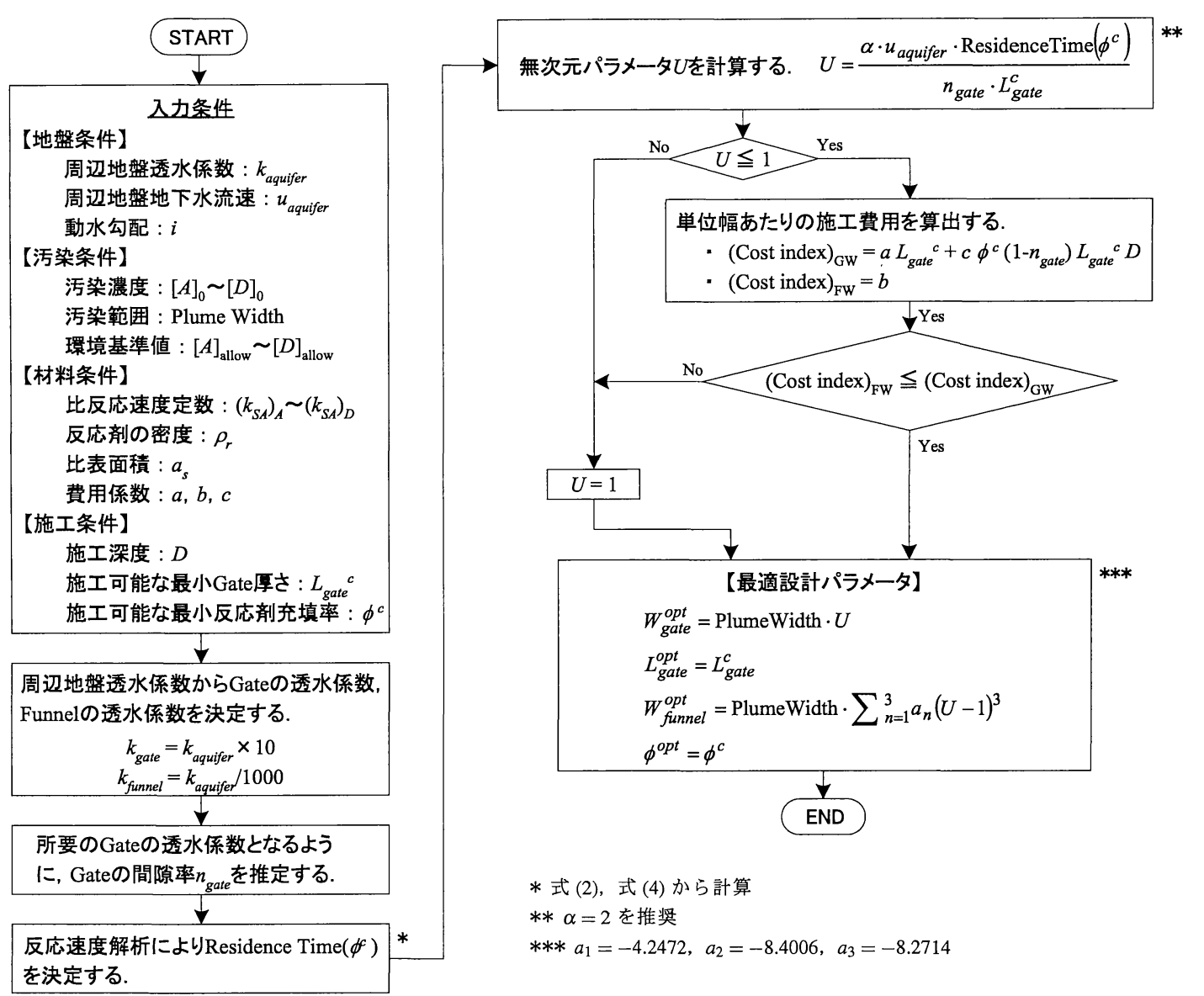

図-32 反応透過壁工法の最適設計法

が $5 \%$ 程度でも，実際の現場で問題となるよう な污染地下水（污染濃度 $1000 \mathrm{mg} / \mathrm{L}$ 以下）は 1 日未満の短い時間で環境基準值以下まで減衰さ れることがわかった.したがって, 反応壁内に励 染地下水を 1 日以上滞留させるような反応透過 壁系を設計すればよいと考えられる．この条件 は十分達成可能であり, 例えば, 反応壁の透水 係数を $5.0 \times 10^{-2} \mathrm{~cm} / \mathrm{s}$, 反応壁の（有効）間隙率 を 0.4, 反応壁内の動水勾配を 1/400（図-6にお ける Gate 内の動水勾配を参考にした）と仮定し た場合, 反応壁の厚さが $1 \mathrm{~m}$ 程度であれば, 反 応壁内に䄷染地下水を 3.7 日程度滞留させるこ とができる。

（2）反応壁の透水性と遮水壁の遮水性が反応透過壁 の性能に与える影響を評価するために, 反応壁 と遮水壁の透水係数をパラメトリックに変化さ せて浸透流解析を行った. その結果, 反応壁の透 水係数が周辺地盤の 10 倍以上であれば, 反応壁 の透水係数の違いにより浄化性能や集水性能に
及ぼす影響はみられなかった。また，遮水壁の透 水係数が周辺地盤の $1 / 1000$ 倍以下であれば, 遮 水壁の透水係数の違いにより浄化性能や集水性 能に及ぼす影響はみられなかった．現場におけ る透水係数の不均一性を考慮すると, 反応壁の 透水係数は周辺地盤透水係数の 10 倍以上, 遮水 壁の透水係数は周辺地盤透水係数の $1 / 1000$ 倍以 下が適していると考えられる。

(3) 反応透過壁工法の最小施工費用を与える設計パ ラメータ（反応壁の幅, 反応壁の厚さ, 遮水壁の 幅, 反応剂充填率) を, 最適化問題として整理し た. その結果, 污染濃度 $1000 \mathrm{mg} / \mathrm{L}$ 以下および洉 染範囲 $15 \mathrm{~m}$ 以下の污染サイトに対しては, 最小 施工費用を与える反応壁の厚さおよび反応剂充 填率の最適値は, 実施工に適さないほど小さな 值であった（ $\left.L_{\text {gate }}^{o p t} \leq 0.1 \mathrm{~m}, \phi^{o p t} \leq 2 \%\right)$. したがっ て, 反応壁の厚さと反応剂充填率は反応透過壁 系の性能ではなく, 反応壁の構造安定性や反応 剂の均一混合等を考慮して決定すべきと考えら 
れる。一方, 反応壁の幅と遮水壁の幅は性能に 著しい影響を及ぼすので, その最適值を求める ことは重要である.なお, 反応壁の厚さと反応 剂充填率の最適值はサイトの活染範囲に依存し ない.

（4）最小の施工費用を与える反応壁の幅と遮水壁 の幅の最適値は, 污染調查より得られる污染 濃度 $[A]_{0}$, 污染範囲 Plume Width と, 現場の 地盤条件・施工条件より得られる周辺地盤地 下水流速 $u_{\text {aquifer }}$, 反応壁の間隙率 $n_{\text {gate }}$, 反応 壁の厚さ $L_{\text {gate }}^{c}$, 反応剂充填率 $\phi^{c}$ から決定さ れる.これらの条件から, 無次元パラメータ $U=\alpha \cdot u_{\text {aquifer }} \cdot$ Residence Time $\left(\phi^{c}\right) / n_{\text {gate }} \cdot L_{\text {gate }}^{c}$ を計算すると, 反応壁の幅の最適值は $W_{\text {gate }}^{\text {opt }}=$ Plume Width $U$, 遮水壁の幅の最適值は $W_{\text {funnel }}^{\text {opt }}$ $=$ Plume Width $\cdot \sum_{n=1}^{3} a_{n}(U-1)^{n}$ として与えら れる.ここに, $a_{1}=-4.2472, a_{2}=-8.4006$, $a_{3}=-8.2714$ である.

反応透過壁工法は, 現状の土壌・地下水污染対策に 関する問題（維持管理費用高騰問題等）から期待さ れる工法の 1 つであるが, 設備導入までの初期費用 が高いという問題点も抱えている. 反応透過壁工法 の性能評価や設計法に関する研究は遮水壁を設置し ない Continuous PRB 工法を対象としたものが多く, 遮水壁を設置する Funnel-and-Gate System 工法を対象 としたものは少ない1),22). 本研究で得られた知見が 反応透過壁工法の適正な設計や普及のための一助と なれば幸いである。

謝辞: 本研究を行うにあたり, 終始適切なご提言を頂 きました京都大学 嘉門雅史 教授, 国立環境研究 所循環社会形成推進廃裹物研究センター 遠藤和人

博士に心から厚く謝意を表します. 反応透過壁工 法の施工情報等のご助言を頂きました熊谷組技術研 究所環境修復グループ 門倉伸行 部長に深く感謝 致します.

\section{参考文献}

1) Starr, R. C. and Cherry, J. A. : In situ remediation of contaminated ground water : the funnel-and-gate system, Ground Water, Vol.32(3), pp.465-476, 1994.

2) Powell, R. M., Blowes, D. W., Gillham, R. W., Schultz, D., Sivavec, T., Puls, R. W., Vogan, J. L., Powell, P. D. and Landis, R. : Permeable Reactive Barrier Technologies for Contaminant Remediation, EPA/600/R-98/125, September, 1998.

3) 地盤工学会 編: 土壌・地下水污染の調查 ·予測 ·対 策, 地盤工学会, pp.82-88, 2002.
4) Cipollone, M. G., Wolfe, N. L. and Hassan, S. M. : Kinetic studies on the use of metallic iron to reduce organic compounds in water under environmental condition, Am Chem Soc, Div Environ Chem, Vol.35, pp.812-814, 1995. (Abstract)

5) Powell, R. M., Puls, R. W., Hightower, S. K. and Sabatini, D. A. : Coupled iron corrosion and chromate reduction : Mechanisms for subsurface remediation, Environ. Sci. Technol., Vol.29, pp.1913-1922, 1995.

6) Cherry, J. A. and Robertson, W. D. : In situ denitrification of septic-system nitrate using reactive porous media barriers : Field trials, Ground Water, Vol.33(1), pp.99-111, 1995.

7) 副島敬道, 伊藤雅子, 今村 聡, 寺尾宏: 透過 性浄化壁工法による硝酸性窒素污染地下水の浄化-2, 地下水・土壤污染とその防止対策に関する研究集会, pp.341-344, 2002.

8) 根岸昌範, 李 昌洙, 下村雅則, 松山明人, 今村 聡: 鉄 粉を用いた有機塩素化合物の浄化対策, 第 2 回環境地 盤工学会シンポジウム, 地盤工学会, pp.35-40, 1999.

9）先崎哲夫, 熊谷祐男: 還元処理による有機塩素化合物 の除去一鉄粉による $1,1,2,2$-テトラクロロエタン の処理, 工業用水, 357, pp.2-7, 1998.

10) 先崎哲夫, 熊谷祐男: 還元処理による有機塩素化合物 の除去 (第 2 報) 一鉄粉によるトリクロロエチレンの 処理, 工業用水, 369, pp.19-25, 1989.

11) 先崎哲夫: 鉄粉によるトリクロロエチレンの処理 (そ の2）, 工業用水, 391, pp.28-29, 1991.

12) Johnson, T. L., Scherer, M. M. and Tratnyek, P. G. : Kinetics of halogenated organic compound degradation by iron metal, Environ Sci Technol, Vol.30, pp.2634-2640, 1996.

13) Tratnyek, P. G., Johnson, T. L., Scherer, M. M. and Eykholt, G. R. : Remediating ground water with zero-valent metals : Chemical considerations in barrier design, Ground Water Monitoring \& Remediation, Vol.XVII, No.4, Fall 1997.

14) Gavaskar, A. R., Gupta, N., Sass, B. M., Janosy, R. J. and O'Sullivan, D. : Permeable Barriers for Groundwater Remediation, Battelle Press, 1998.

15) 斉藤 昊: はじめて学ぶ大学の物理化学, 科学同人, pp.77-97, 2000.

16）山口柏樹：土質力学（講義と演習）, 技報堂出版, pp.64-65, 2000.

17）日野幹夫, 砂田憲吾, 太田猛彦, 渡辺邦夫 : 洪水の数值 予報一その第一歩一, 森北出版, pp.47-51, 1989.

18) van Genuchten, M. Th. : A closed-form equation for predicting the hydraulic conductivity of unsaturated soils, Soil Sci. Soc. Am. J., Vol.44, pp.892-898, 1980.

19) Rawls, W.J., Brakensiek, D.L., and Saxton, K.E. : Estimating soil water properties, Transactions, ASAE, Vol.25(5), 
pp.1316-1320 and 1328, 1982.

20) Carsel, R.F. and Parrish, R.S. : Developing joint probability distributions of soil water retention characteristics, Water Resour Res, Vol.24, pp.755-769, 1988.

21) Frind, E. O. and Matanga, G. B. : The dual formulation of flow for contaminant transport modeling : 1. Review of theory and accuracy aspects, Water Resour Res, Vol.21(2), pp.159-169, February, 1985.

22) Shikaze, S. : $3 \mathrm{D}$ numerical modeling of groundwater flow in the vicinity of funnel-and-gate systems, ARA-TR-96-5286-

1, Prepared by Applied Research Associates, Inc. for U.S. Air Force, Tyndall Air Force Base, FL. April, 1996.

（2003.5.16 受付）

\section{OPTIMUM DESIGN OF PERMEABLE REACTIVE BARRIERS FOR CONTAMINATED GROUNDWATER REMEDIATION}

\section{Hiroyuki ISHIMORI, Takeshi KATSUMI and Ryoichi FUKAGAWA}

Performance of permeable reactive barriers for contaminated groundwater remediation was evaluated using FEM seepage analysis. The retention time and the capture width were calculated on the funneland-gate system having different geometries, in order to evaluate the effects of these geometries on the performance of funnel-and-gate system. Based on the calculated results, costs associated with the installation of funnel-and-gate system satisfying a certain performance were obtained to estimate the cost-effective geometry. Finally, optimum design flow for permeable reactive barriers was proposed. 